\title{
Lhx2 Determines Odorant Receptor Expression Frequency in Mature Olfactory Sensory Neurons
}

\author{
Guangfan Zhang, ${ }^{1}$ William B. Titlow, ${ }^{1}$ Stephanie M. Biecker, ${ }^{1}$ Arnold J. Stromberg, ${ }^{2}$ and ${ }^{\circledR}$ Timothy S. \\ McClintock ${ }^{1}$
}

DOI:http://dx.doi.org/10.1523/ENEURO.0230-16.2016

${ }^{1}$ Department of Physiology, University of Kentucky, Lexington, Kentucky 40536-0298, and ${ }^{2}$ Department of Statistics, University of Kentucky, Lexington, Kentucky 40536-0082

\begin{abstract}
A developmental program of epigenetic repression prepares each mammalian olfactory sensory neuron (OSN) to strongly express one allele from just one of hundreds of odorant receptor (OR) genes, but what completes this process of OR gene choice by driving the expression of this allele is incompletely understood. Conditional deletion experiments in mice demonstrate that Lhx2 is necessary for normal expression frequencies of nearly all ORs and all trace amine-associated receptors, irrespective of whether the deletion of $L h x 2$ is initiated in immature or mature OSNs. Given previous evidence that Lhx2 binds OR gene control elements, these findings indicate that Lhx2 is directly involved in driving OR expression. The data also support the conclusion that OR expression is necessary to allow immature OSNs to complete differentiation and become mature. In contrast to the robust effects of conditional deletion of $L h \times 2$, the loss of Emx2 has much smaller effects and more often causes increased expression frequencies. Lhx2:Emx2 double mutants show opposing effects on Olfr15 expression that reveal independent effects of these two transcription factors. While Lhx2 is necessary for OR expression that supports OR gene choice, Emx2 can act differently; perhaps by helping to control the availability of OR genes for expression.
\end{abstract}

Key words: enhancer; gene expression; olfaction; promoter; smell; transcription

\section{Significance Statement}

The nervous system develops myriad different types of neurons, many having numerous subtypes. The olfactory epithelium takes this to an extreme, with $>1000$ different subtypes of the olfactory sensory neuron (OSN), each defined by the expression of a single odorant receptor (OR) gene. We demonstrate that Lhx2 is the homeodomain transcription factor necessary to drive the expression of OR genes. By stabilizing the expression of a single OR gene and consequently triggering OSN maturation, Lhx2 drives the events that complete the process of OR gene choice, thereby defining the role of each OSN in odor detection and discrimination.

\section{Introduction}

Odorant receptors (ORs), which often number $>1000$ and therefore comprise the largest family of mammalian genes, are G-protein-coupled receptors that evolved to

Received August 7, 2016; accepted October 10, 2016; First published October 17, 2016.

The authors declare no competing financial interests.

Author contributions: T.S.M. designed research; G.Z., W.B.T., S.M.B., and T.S.M. performed research; A.J.S. and T.S.M. analyzed data; T.S.M. wrote the paper.

This research was supported by National Institutes of Health Grants R01DC-007194, R01-DC-002736, K18-DC-013343, and R21-DC-014468 to T.S.M.; and UL1-TR-001998 and 5P20-GM-103436-15 to A.J.S. transduce the binding of odorant molecules into intracellular signals (DeMaria and Ngai, 2010). In a process called OR gene choice, each olfactory sensory neuron (OSN) selects one allele of one OR gene for high-level expres-

Correspondence should be addressed to Timothy S. McClintock, Department of Physiology, University of Kentucky, 800 Rose Street, Lexington, KY 40536-0298. E-mail: mcclint@uky.edu.

DOI:http://dx.doi.org/10.1523/ENEURO.0230-16.2016

Copyright (C) 2016 Zhang et al.

This is an open-access article distributed under the terms of the Creative Commons Attribution 4.0 International, which permits unrestricted use, distribution and reproduction in any medium provided that the original work is properly attributed. 
sion (Rodriguez, 2013). The choice is random, except that each OR gene is available for expression only in a defined region of the olfactory epithelium called a zone. This exquisite specificity is essential for odor discrimination (Fleischmann et al., 2008).

Repressive chromatin modifications characteristic of heterochromatin are fundamental to OR gene choice (Lyons and Lomvardas, 2014). These modifications require the histone methyltransferases Kmt1c and Kmt1d, appear early in the OSN cell lineage before the initiation of OR gene expression, and ultimately result in the compaction of OR genes into heterochromatin compartments in OSN nuclei (Magklara et al., 2011; Clowney et al., 2012; Lyons et al., 2014). Derepression of OR alleles occurs in immature OSNs, or perhaps their immediate progenitors, and requires the histone demethylase Kdm1a (Lyons et al., 2013). Once the expression of an OR allele initiates, OR protein accumulation in the ER triggers a feedback signal that represses Kdm1a so that no other OR allele can be derepressed (Dalton et al., 2013). The expression of an OR appears to trigger the final stages of OSN differentiation, resulting in a mature OSN that expresses a single OR allele.

What drives transcription from the newly derepressed OR allele is not fully understood. However, the enhancers and proximal promoters of OR genes contain two conserved elements, homeodomain sites and Olf1/Ebf1 (O/E-like) sites, whose mutation reduces OR gene expression (Bozza et al., 2002; Serizawa et al., 2003; Rothman et al., 2005; Hoppe et al., 2006; Michaloski et al., 2006; Vassalli et al., 2011; Clowney et al., 2012; Plessy et al., 2012; Markenscoff-Papadimitriou et al., 2014). O/E-like sites are bound by Ebf transcription factors, but whether they are required for OR gene expression is uncertain (Wang et al., 2004). Yeast one-hybrid experiments reveal that the homeodomain sites can be bound by several transcription factors, but Lhx2 and Emx2 are the two most strongly implicated in OR gene expression (Hirota and Mombaerts, 2004; Hoppe et al., 2006; Hirota et al., 2007; Mclntyre et al., 2008). Unfortunately, germ-line deletions of these transcription factors are confounded by large reductions in OSN number. Emx2-null mice have $40 \%$ fewer mature OSNs, and $L h \times 2-$ null mice are even more strongly affected, being nearly devoid of mature OSNs and having fewer immature OSNs (Hirota and Mombaerts, 2004; Kolterud et al., 2004).

Lhx2 is a LIM (Lin-11, Isl-1, Mec-3) homeodomain transcription factor that is important for the development of diverse tissues. In the nervous system, it tends to be critical for neural versus glial specification. For example, it regulates progenitor cell fate and proliferation in the cerebral cortex, hypothalamus, and retina, often by controlling the expression of transcription factors and signaling proteins (Chou and O'Leary, 2013; Gordon et al., 2013; Shetty et al., 2013; Roy et al., 2014; Hsu et al., 2015). Lhx2 also acts later in cell differentiation, supporting the final differentiation of tanycytes in the hippocampus and Müller glia in the retina (Salvatierra et al., 2014; de Melo et al., 2016). Emx2 (empty spiracles homeobox 2) has similar roles in neural development. It contributes to the de- velopment of portions of the telencephalon, where it regulates cell specification and neural circuit formation (Pellegrini et al., 1996; Fukuchi-Shimogori and Grove, 2003; Hamasaki et al., 2004; O'Leary et al., 2007; Dwyer et al., 2011).

To test the effects of the loss of Lhx2 and Emx2 on OR expression, we bred mice that allow conditional deletion of $L h \times 2$ and $E m \times 2$ in OSNs, finding that Lhx2 is necessary for OR gene expression and consequent differentiation of OSNs. Emx2, in contrast, appears to be necessary for OR gene expression in a distinctly different way.

\section{Materials and Methods}

\section{Mice}

123Cre transgenic mice and OmpCre gene-targeted mutant mice, respectively, were the gifts of Dr. Y. Yoshihara (RIKEN Brain Science Institute, Wako, Japan) and Dr. P. Mombaerts (Max Planck Research Unit for Neurogenetics, Frankfurt am Main, Germany). Lhx2 $2^{\mathrm{fl} /+}$ mice and $E m \times 2^{\mathrm{fl} /+}$ mice were the gifts of Dr. D. O'Leary (Salk Institute for Biological Studies, La Jolla, CA). Both sexes were used in all experiments, and no mouse carried more than one copy of Cre recombinase.

Z/EG reporter mice (Novak et al., 2000) were purchased from The Jackson Laboratory (https://www.jax.org/strain/ 003920).

All treatments and procedures used with mice were approved by the university institutional animal care and use committee and were consistent with National Institutes of Health guidelines on animal use in research.

\section{DNA microarray}

Olfactory mucosae were dissected from mice of the desired age and genotype. Total RNA was prepared using TriReagent as directed by the manufacturer (Molecular Resource Center).

Given that ORs are detectably expressed by age postnatal day 1 (P1; Rodriguez-Gil et al., 2009) to best match previous work on germ-line-targeted deletion of Emx2 (McIntyre et al., 2008) experiments used age P1 neonatal $E m \times 2^{\mathrm{fl} /+}$ mice. Conditional deletion of $L h \times 2$ in immature OSNs was also assessed in neonates at age P3. Conditional deletion of $L h \times 2$ in mature OSNs and the double deletion of $L h \times 2$ and $E m \times 2$ were assessed in juvenile mice at age P26. Each of the two or three litters from which conditional knock-out mice were obtained for an experiment also contributed control mice. Preliminary testing showed that OR expression in 123Cre:Lhx $2^{\mathrm{fl} /+}$ mice did not differ from $\mathrm{Lhx} 2^{\mathrm{fl} /+}$ mice, arguing that the deletion of a single $L h \times 2$ allele has no effect. Littermate controls therefore were any genotype where no more than one allele could undergo recombination.

Preparation of samples for microarray hybridization and initial data reduction were performed as described previously by the University of Kentucky Microarray Core Facility, using equal amounts of total RNA from each sample (Mclntyre et al., 2008). GeneChip Mouse Gene 1.0 ST arrays were used to quantify mRNAs. Data were analyzed at the transcript cluster level, which combines the signals from the probe sets representing all exons of each gene 
Table 1. GeneChip Mouse Gene 1.0 ST array probe set OR transcript clusters

\begin{tabular}{lll}
\hline Type & Transcript clusters $(n)$ & OR genes $(n)$ \\
Single functional gene & 996 & 994 \\
Single pseudogene & 34 & 34 \\
Multiple gene & 112 & 104 \\
No functional gene & 2 &
\end{tabular}

into a single value. This GeneChip has 1142 clusters of exon-level probe sets, called transcript clusters, which represent 1098 functional OR genes (Table 1). Given that the vast majority of OR genes are represented unambiguously by a transcript cluster, we use the terms OR gene or OR mRNA in reporting and discussing these data. Trace amine-associated receptor (TAAR) mRNA data from the GeneChip were also analyzed. Except for Taar8a, each TAAR gene is represented by at least one unambiguous transcript cluster. In mice, Taar7c is a pseudogene.

To normalize to the number of mature OSNs present in the samples of olfactory mucosae used in these experiments, we took advantage of the recent identification of hundreds of mature and immature OSN-specific mRNAs (Nickell et al., 2012). There are 581 mature OSN-specific mRNAs and 697 immature OSN-specific mRNAs that are consistently detected by Affymetrix GeneChip Mouse Gene 1.0 ST arrays. The average difference in the abundance of the 581 mature OSN-specific mRNAs between mutants and littermate controls was used as a normalization factor. Statistical analysis of the data was performed via $t$ tests. Correction for multiple testing was performed using a stepwise false discovery rate (FDR) procedure (Benjamini and Hochberg, 1995; Storey and Tibshirani, 2003a,b). The microarray data have been deposited at Gene Expression Omnibus (superseries record GSE74527, subseries GSE74522-GSE74526).

\section{In situ hybridization and immunofluorescence}

The in situ hybridization methods that Ishii et al. (2003, 2004) have described in detail were followed using 10-12 $\mu \mathrm{m}$ coronal cryosections from mice in the age range P21-P34. We have previously described the use of these procedures to locate cells expressing $>300$ mRNAs in olfactory epithelia (Sammeta et al., 2007; Nickell et al., 2012; Heron et al., 2013). cDNA fragments of each mRNA were amplified by PCR from olfactory mucosal cDNA and cloned into pBluescript (Table 2). The fragments chosen were selected to have $<90 \%$ identity with any other mouse mRNA. Recombinant RNA probes labeled with digoxigenin were prepared for each mRNA species. Sense controls were invariably negative.

Immunohistochemistry was also performed on coronal cryosections from the tissue of age P31-P34 mice, prepared as described above except that fixation in $4 \%$ paraformaldehyde was performed for only 60-90 min rather than overnight. These frozen sections were thawed and permeabilized in PBS, $\mathrm{pH} 7.4$, with $1 \%$ Triton X-100. Blocking buffer (2\% BSA and $0.4 \%$ Triton X-100 in PBS) was applied for $1 \mathrm{~h}$ at room temperature followed by incubation in primary antibody diluted in the blocking buffer overnight at $4^{\circ} \mathrm{C}$. Sections were washed with $0.05 \%$
Table 2. In situ hybridization probe cDNAs

\begin{tabular}{lll}
\hline Gene symbol & NCBI accession no. & Region used \\
Omp & NM_011010 & 569-1064 \\
Gap43 & NM_008083 & $369-835$ \\
Lhx2 & NM_001290646 & $532-1251$ \\
Olfr6 & NM_206897 & $237-741$ \\
Olfr15 & NM_008762 & $172-658 ; 477-932$ \\
Olfr17 & NM_020598 & $208-684$ \\
Olfr90 & NM_146477 & $371-866$ \\
Olfr129 & NM_146327 & $692-1139$ \\
Olfr156 & NM_019474 & $125-598$ \\
Olfr308 & NM_146621 & $25-882$ \\
Olfr545 & NM_146840 & $1-827$ \\
Olfr615 & NM_147080 & $1-942$ \\
Olfr963 & NM_001011827 & $138-851$ \\
Olfr1440 & NM_146684 & $229-726$ \\
Olfr1465 & NM_001011841 & $35-454$ \\
\hline
\end{tabular}

Probes from the two fragments of Olfr15 give identical results. The region of Lhx2 used is contained within exons $1-3$, the floxed region of the mutated Lhx2 gene.

Tween-20 in PBS for 30 min and then incubated with Cy3-conjugated secondary antibody diluted in PBS. Nuclei were counterstained using Hoechst 33342 (catalog \#H1399, Invitrogen). The anti-Casp3 rabbit polyclonal antibody specifically detects a $17 \mathrm{kDa}$ cleavage fragment produced by apoptosis-initiating proteases. The specificity of this antibody is well documented (Hu et al., 2000; Cheong et al., 2003; Kaiser et al., 2008). Phosphorylated histone 3, which increases abruptly as chromatin condenses during mitosis, was detected using a rabbit polyclonal antibody (catalog \#06-570, Millipore) at a 1:200 dilution. The specificity of this antibody for its intended target has long been known (Mauser et al., 2002). Rabbit anti-Gap43 (AB5220, Millipore) was used at a 1:200 dilution to identify immature OSNs and goat anti-olfactory marker protein (OMP; catalog 544-10001, Wako) was used at a dilution of 1:1000 to identify mature OSNs. The specificity of these two antibodies for their intended targets is widely recognized (Baker et al., 1989; Song et al., 2002; Inaki et al., 2004; Koo et al., 2005; McIntyre et al., 2010; Miller et al., 2010). CD68 was detected using a rat antibody (clone FA-11, catalog \#MCA1957, AbD Serotec) at a dilution of 1:500 in a different blocking buffer, as follows: $2 \%$ normal donkey serum, $0.03 \%$ Triton $X-100$ in PBS. The specificity of this antibody for CD68 is widely accepted and has been confirmed by targeted gene deletion of CD68 (Rabinowitz and Gordon, 1991; Song et al., 2011).

For secondary antibodies, a Cy3-conjugated donkey anti-rabbit IgG (catalog \#711-165-152, Jackson ImmunoResearch) and a Cy3-conjugated donkey anti-goat IgG (catalog \#705-165-147, Jackson ImmunoResearch) were used at a dilution of 1:1000 in blocking buffer. A Cy3conjugated donkey anti-rat IgG (catalog \#712-165-150, Jackson ImmunoResearch) was used at 1:500 in 2\% normal donkey serum and $0.03 \%$ Triton X-100 in PBS.

Wide-field images of labeling in tissue sections were obtained on a Nikon Diaphot 300 inverted microscope using a Spot 2e camera and Spot software version 4.0.6 through a $40 \times / 0.75$ numerical aperture Plan Fluor objec- 
tive, a $20 \times / 0.75$ numerical aperture Plan Apo differential interference contrast (DIC) objective, a $10 \times / 0.45$ numerical aperture Plan Apo DIC objective, or a $4 \times / 0.13$ numerical aperture Plan objective. Images were processed in Adobe Photoshop only by adjusting size and brightness. To produce final figures, images were combined and labeled in Canvas Draw version 2.0 (ACD Systems).

For counts of labeled cells, coronal sections matched for anterior-posterior position between mutant and control were selected and used to generate an average count per linear distance along the olfactory epithelium for each mouse. The zonal expression patterns of ORs presents a special problem when normalizing the number of OSNs expressing an OR to the amount of olfactory epithelium assessed because the boundaries of $\mathrm{OR}$ expression zones are difficult to locate. We therefore chose a conservative approach, including only the distance between the outermost OSNs expressing the targeted OR. This overestimates the frequency of labeled OSNs, and therefore favors making a type II error over a type I error. In cases where OR genes are too rarely expressed to use this strategy, we measured the number of labeled OSNs per tissue section.

Cell counts of OR expression were normalized to the fractional loss of mature OSNs in the mutant mice, as measured by in situ hybridization for Omp mRNA from adjoining sections of the same mice. The average difference from control genotypes was used to calculate a correction factor that was applied to the counts.

For consistency in the immunohistochemistry data, counts of immunoreactive cells were made along the septum. To restrict the measure of mitosis to progenitors of OSNs, only cells immunoreactive for phosphorylated histone 3 in the basal layer of the olfactory epithelium were counted. As OSNs are the only cells in which genes were recombined in this project, cells immunoreactive for the active fragment of Casp3 were counted in the OSN layers of the olfactory epithelium. In contrast, all CD68immunoreactive cells within the olfactory epithelium were counted. Correction for multiple testing within the cell count data was performed using a stepwise FDR procedure (Benjamini and Hochberg, 1995; Storey and Tibshirani, 2003a,b). The average values calculated for these cell counts are reported with their SDs.

In fluorescent images from sections of Z/EG reporter mice, nuclei inside $\mathrm{GFP}^{+}$and $\mathrm{GFP}^{-}$OSN cell bodies were counted per linear distance along the olfactory epithelium.

\section{Results}

\section{Conditional Lhx2 deletion in immature OSNs decreases OR expression frequency}

In addition to expression in basal cells of the olfactory epithelium, Lhx2 is present in OSNs, the cells that express OR genes (Hirota and Mombaerts, 2004; Kolterud et al., 2004). Lhx2 interacts directly with OR gene promoters in yeast one-hybrid assays and binds OR gene enhancers in vivo (Hoppe et al., 2003; Hirota and Mombaerts, 2004; Markenscoff-Papadimitriou et al., 2014). These data predict that Lhx2 plays a direct and positive role in OR gene expression.

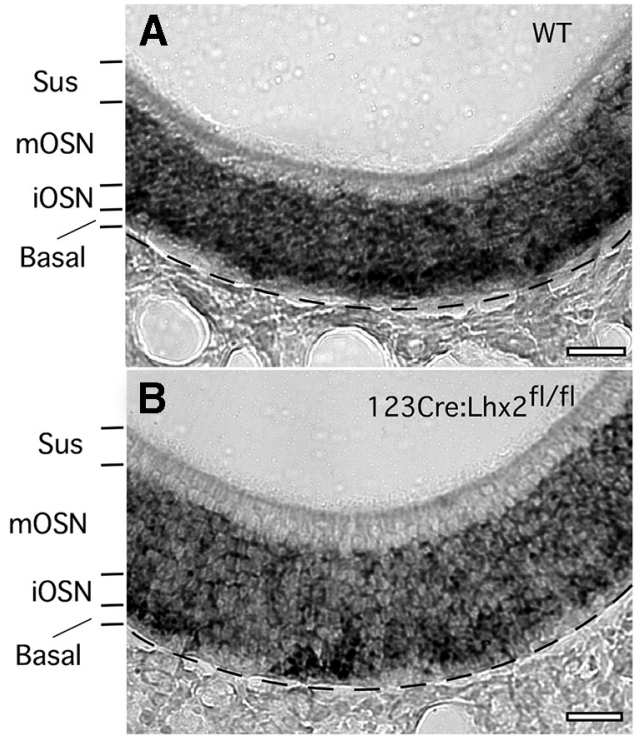

Figure 1. Most OSNs in 123Cre:Lhx $2^{\mathrm{fl} / \mathrm{fl}}$ mice continue to express Lhx2. $\boldsymbol{A}$, In situ hybridization for Lhx2 mRNA in a wild type (WT) mouse. $\boldsymbol{B}$, In situ hybridization for Lhx2 mRNA in a 123Cre: Lhx $2^{\text {fl/fl }}$ mouse. Sus, Sustentacular cell layer; mOSN, mature OSN cell layer; iOSN, immature OSN cell layer; Basal, basal cell layer. Scale bars, $40 \mu \mathrm{m}$.

To try to minimize the loss of OSNs that would be expected if OR expression fails, and that confounds the interpretation of data from germ-line deletion of $L h x 2$ (Hirota and Mombaerts, 2004; Kolterud et al., 2004; Hirota et al., 2007), we turned to a conditional deletion strategy. We obtained 123Cre mice in which Cre expression begins in immature OSNs (Takeuchi et al., 2010). We produced $123 \mathrm{Cre}:$ Lhx $2^{\mathrm{fl} / \mathrm{fl}}$ mice by crossing $123 \mathrm{Cre}$ mice with floxed Lhx2 mice in which LoxP sites bound the first three exons of $L h x 2$ (Chou et al., 2009). Using in situ hybridization with a probe sequence contained within these three floxed exons, we find that the deletion of $L h \times 2$ is incomplete in these mice (Fig. 1). To confirm that Cre recombinase driven by the 123 promoter is effective, we crossed 123Cre mice with Z/EG mice. GFP expression reports Cre-mediated recombination in $48 \pm 1 \%$ ( $n=2$ mice) of the cell bodies in the OSN layers of these mice (Fig. 2A). All of the fluorescent cells show the morphology of neurons. No fluorescence is present in other cells or cell processes found in the OSN layers, such as infiltrating macrophages, the basal processes of sustentacular cells, and the ducts of Bowman's glands. On average, the basal end of the GFP fluorescent cell body layer is $16.2 \pm 0.8 \%$ of the distance from the basement membrane to the apical surface in these mice, which is consistent with recombination in immature OSNs. Given that complete deletion of $L h \times 2$ might result in the loss of most mature OSNs and thereby confound further experiments, we reasoned that incomplete deletion could provide a situation that allows the effects on OR expression to exceed the loss of OSNs.

In 123Cre:Lhx $2^{\text {fl/fl }}$ mice, the numbers of Gap $43^{+}$immature OSNs are identical to those of control mice (Fig. $2 B-E$ ), and the average abundance of 697 immature OSN- 

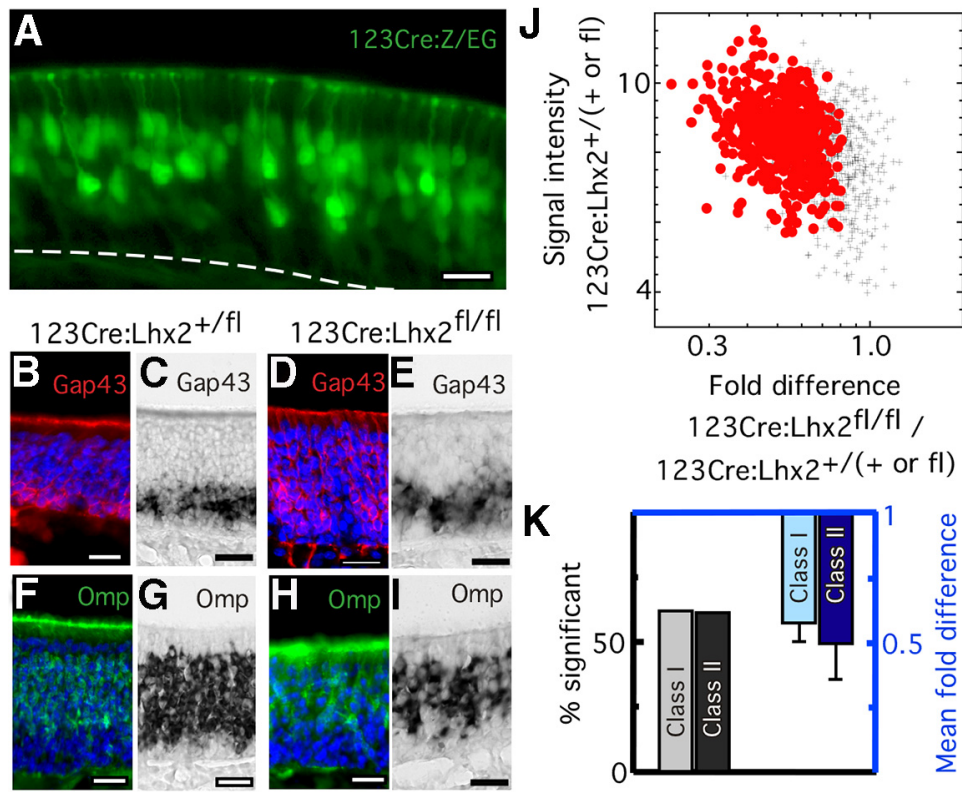

Figure 2. Conditional deletion of $L h x 2$ in immature OSNs decreases the abundance of most OR mRNAs. A, In 123Cre:Z/EG mice, recombination-dependent GFP expression marks OSNs in the immature and mature OSN layers of the olfactory epithelium. Dashed line, location of the basal lamina separating the olfactory epithelium and lamina propria. Scale bar, $20 \mu \mathrm{m}$. B-E, Gap43 immunoreactivity $(\boldsymbol{B}, \boldsymbol{D})$ and in situ hybridization for Gap43 mRNA $(\boldsymbol{C}, \boldsymbol{E})$ identify immature OSN cell bodies in $123 \mathrm{Cre}$ :Lhx2 $2^{\mathrm{fl} / \mathrm{fl}} \mathrm{mice}(\boldsymbol{D}, \boldsymbol{E})$ and littermate controls $(\boldsymbol{B}, \boldsymbol{C})$. $\boldsymbol{F}-\boldsymbol{I}$, Omp immunoreactivity $(\boldsymbol{F}, \boldsymbol{H})$ and in situ hybridization for Omp mRNA $(\boldsymbol{G}, \boldsymbol{I})$ identify mature OSN cell bodies in 123Cre:Lhx2 ${ }^{\text {fl/fl }}$ mice $(\boldsymbol{H}, \boldsymbol{I})$ and littermate controls $(\boldsymbol{F}, \boldsymbol{G})$. Scale bars, $20 \mu \mathrm{m}$. $\boldsymbol{J}$, In 123 Cre:Lhx $2^{\mathrm{fl} / \mathrm{fl}}$ mice, the abundance of 676 OR mRNAs decreases $(p<0.01 ; n=4$; FDR $<1 \%)$. $\bullet$, Significant decrease; + , no difference from littermate controls. $\boldsymbol{K}$, The percentage of class I ORs affected by Lhx2 deletion in immature OSNs is very similar to the percentage of Class II ORs affected, and the magnitude of the decreases are similar for both classes of ORs. Error bars represent SDs.

specific mRNAs (Nickell et al., 2012) is similarly unaffected. The number of mature OSNs is slightly reduced in 123Cre:Lhx2 $2^{\mathrm{fl} / \mathrm{fl}}$ mice (Fig. $\left.2 F-l\right)$. The average abundance of 581 mature OSN-specific mRNAs (Nickell et al., 2012) is $86 \pm 14 \%$ that of controls $(n=4$ mice), and the thickness of the layer of $\mathrm{Omp}^{+}$OSN cell bodies after in situ hybridization is $82 \%$ that of controls on average. This small decrease indicates a difference in the survival or production of mature OSNs compared with control littermates.

When assessing the abundance of OR mRNAs, the effect of a small decrease in mature OSN number can be eliminated by simple normalization to the extant fraction of mature OSNs as long as accelerated OSN turnover is not responsible for the decrease in mature OSNs. To test the turnover of OSNs, we measured the frequency of apoptosis in the OSN layers of the olfactory epithelium by active Casp3 immunoreactivity. 123Cre:Lhx2 $2^{\mathrm{fl} / \mathrm{fl}}$ mice show no difference from littermate controls in this measure of apoptosis ( $p=0.5627, n=3$ mice), demonstrating that OSN turnover is near normal levels in these mice. The measures of OR mRNA abundance can therefore be safely adjusted by normalization to the fraction of mature OSNs present.

In 123Cre:Lhx2 $2^{\mathrm{fl} / \mathrm{fl}}$ mice, the predominant effects on mRNA abundance are on OR mRNAs, which is reminiscent of our assessment of Emx2 germ-line mutants (Mclntyre et al., 2008). The significantly affected mRNAs are mostly ORs, and OR mRNAs show larger effects compared with littermate controls than other types of tran- scripts. Even after correction for the 14\% decrease in mature OSNs, 676 OR mRNAs are significantly less abundant in 123Cre:Lhx ${ }^{\mathrm{fl} / \mathrm{fl}}$ mice than in control mice (Fig. 2J; $p<0.01$; FDR $<1 \%$ ). Implicit in the finding of significant differences in the normalized data, but worth noting explicitly, is that the $14 \%$ loss of mature OSNs is incapable of accounting for the decreased abundance of OR mRNAs. The average reduction for all OR mRNAs is $41 \%$ after normalization. For the 676 OR mRNAs with a significant decrease, the average reduction is $50 \%$, arguing that a fraction of OSNs must be experiencing altered OR expression.

Data from germ-line Lhx2 knockouts suggested that Lhx2 might act specifically on the class II OR genes, which arose during mammalian evolution (Hirota et al., 2007). However, in 123Cre:Lhx2 $2^{\mathrm{fl} / \mathrm{fl}}$ mice the affected mRNAs include both the more evolutionarily ancient class I ORs, which are recognizably similar to the ORs of fishes, and the larger, more diverse group of class II ORs (Fig. 2K). Class I and class II OR mRNAs show similar reductions in quantity, and similar fractions of ORs are significantly affected.

Some OSNs use TAARs, rather than ORs, to detect odor molecules. Like ORs, TAARs are G-protein-coupled receptors. All but Taar1 of the 14 functional TAAR genes in mice appear to be expressed in OSNs, where they act as receptors for amine-containing odorants (Liberles and Buck, 2006; Johnson et al., 2012). Six TAAR mRNAs (Taar7d,e,f, Taar8b,c, and Taar9) are significantly reduced in 123Cre:Lhx $2^{\mathrm{f} / \mathrm{fl}}$ mice. 

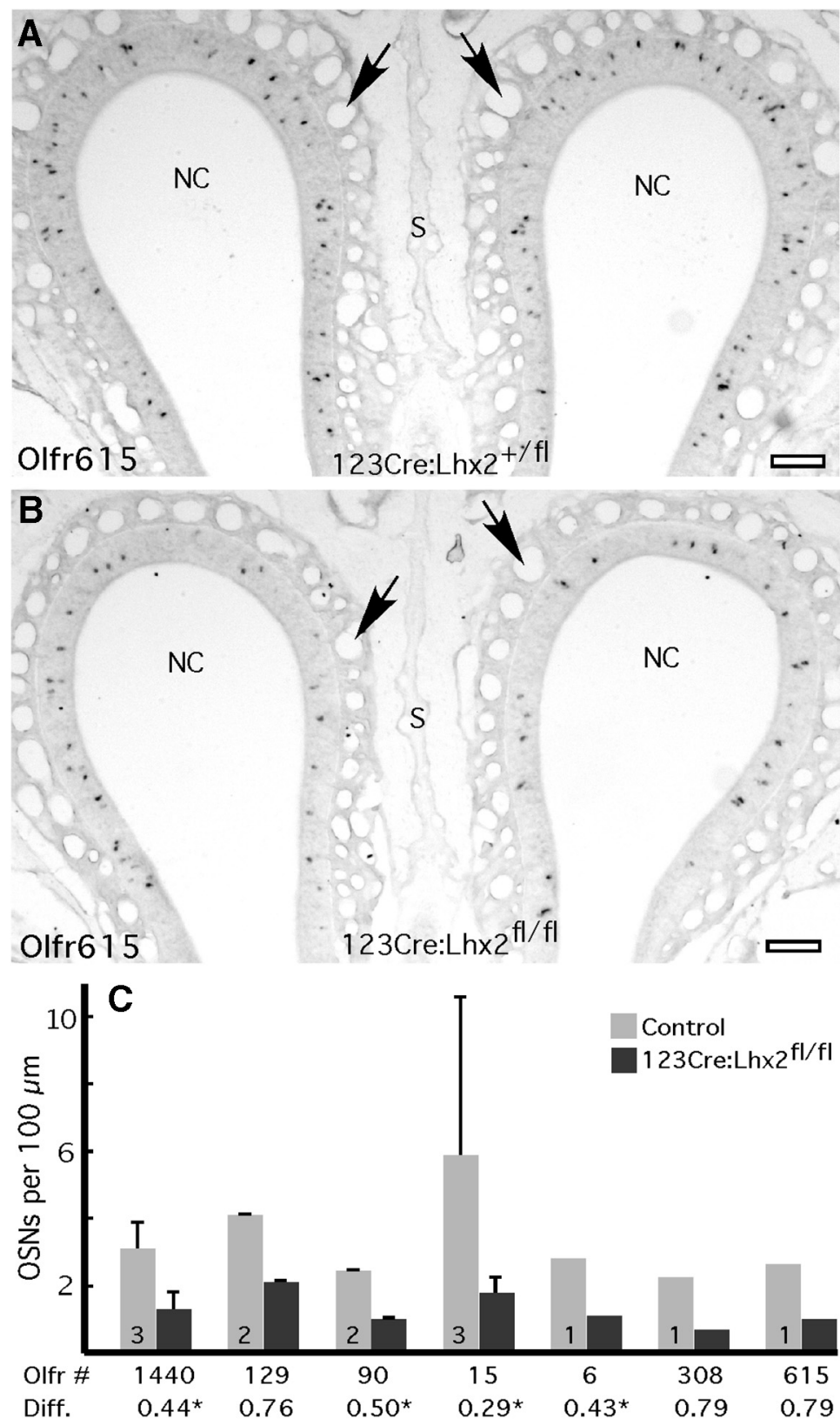

Figure 3. Conditional deletion of $L h x 2$ in immature OSNs reduces OR gene expression frequencies. A, In situ hybridization for Olfr615 labels scattered OSNs in the dorsal olfactory epithelium. B, In 123Cre:Lhx2 ${ }^{\mathrm{fl} / \mathrm{fl}}$ mice, the frequency of OSNs expressing Olfr615 appears to be reduced. $\boldsymbol{C}$, Normalized cell counts show that ORs are consistently less frequently expressed in $123 \mathrm{Cre}$ :Lhx ${ }^{\text {fl/fl }}$ mice compared with littermate controls. Numbers in control bars are the numbers of littermate pairs tested. Diff., Normalized fold differences from the microarray experiment; *Significant difference $(p<0.01 ; n=4$; FDR $<1 \%)$. NC, Air space of the nasal cavity; $\mathrm{S}$, nasal septum; arrows, blood vessels in the lamina propria. Scale bars, $100 \mu \mathrm{m}$.

The large effects on OR mRNA abundance derive from relatively small effects on Lhx2 mRNA abundance. In samples of olfactory mucosae from 123Cre:Lhx $2^{\mathrm{fl} / \mathrm{fl}}$ mice, Lhx2 mRNA is decreased by only $15 \%(p=0.0952, n=$ 4). This small reduction in Lhx2 mRNA abundance is consistent with the data shown in Figure 1, and Figure $2 A$ similarly predicts that the recombination of both $L h x 2$ alleles occurs in only a fraction of immature OSNs.

The decreased abundance of OR mRNAs arises from reduced frequencies of $O R$ expression rather than from reduced amounts of OR mRNA per OSN. For OR mRNAs that decrease in abundance, in situ hybridization consistently reveals fewer OSNs expressing each OR tested. Figure 3 shows an example of a moderately affected mRNA, Olfr615, along with quantitative data on differences in expression frequencies for seven ORs. Even OR genes that do not reach our conservative criteria for significance in the expression profiling experiment, such as Olfr308, Olfr129, and Olfr615, consistently show lower frequencies of expression. The OR mRNA in each OSN is one of the most abundant transcripts in the cell; thus, the latency to the appearance of the signal for OR mRNAs 
during in situ hybridization ( $<24 \mathrm{~h}$ in our hands) is shorter than that of most mRNAs. Allowing the reaction to develop for $48 \mathrm{~h}$ in conditional deletion mice does not increase the frequency of labeled OSNs.

One way for the loss of Lhx2 to cause changes in OR mRNA abundance and OR expression frequency is to disrupt the patterns of zonal expression of OR genes. However, the in situ hybridization data reveal that reduced frequencies of OR expression are not accompanied by changes in the zonal patterns of OR expression in 123Cre: Lhx $2^{\mathrm{f} / \mathrm{fl}}$ mice. Each of the seven OR mRNAs tested in $123 \mathrm{Cre}: \mathrm{Lh} \times 2^{\mathrm{fl} / \mathrm{fl}}$ mice is transcribed from a gene that continues to be expressed in the region of the olfactory epithelium in which the OR is normally expressed, albeit less frequently. Altered zonal expression patterns are not responsible for the effects that we observe.

\section{Lhx2 deletion in mature OSNs decreases OR expression frequency}

The data from 123Cre:Lhx $2^{\mathrm{fl} / \mathrm{fl}}$ mice confirm that Lhx2 has a positive effect on OR expression and is needed for the development of normal OR expression frequencies. However, once OSNs select a single OR allele for expression and become mature OSNs, the repressive epigenetic modification of OR gene loci might be immutable, permanently preventing the expression of any other OR genes. If this is true-and if most mature OSNs survive the loss of OR expression-the deletion of Lhx2 after OSNs reach maturity should have little effect on OR expression frequencies, but might decrease the amount of OR mRNA per OSN. Alternatively, if the feedback mechanisms that prevent the expression of additional OR genes must be continuously active in order to maintain the singularity of the OR gene choice, or if OR expression simply ceases, the loss of Lhx2 in mature OSNs could result in altered OR expression frequencies.

To drive the expression of Cre recombinase specifically in mature OSNs, we used Omp-Cre mice (Li et al., 2004). These mice have a targeted insertion of Cre into the Omp gene locus, which is expressed only in mature OSNs in the olfactory epithelium and rarely expressed in other tissues (Farbman and Margolis, 1980; Monti Graziadei, 1983). In Omp-Cre mice carrying the Z/EG reporter transgene, $41 \pm 1 \%(n=3$ mice) of cells in the mature OSN layer of the epithelium show GFP fluorescence (Fig. 4A), demonstrating Cre recombinase activity in mature OSNs. On average, the basal end of the GFP fluorescence layer is $34.4 \pm 3.6 \%$ of the distance from the basement membrane to the apical surface, which is consistent with labeling restricted to mature OSNs.

As in 123Cre:Lhx $2^{\mathrm{fl} / \mathrm{fl}}$ mice, recombination of $L h x 2$ is successful in OmpCre:Lhx $2^{\mathrm{fl} / \mathrm{fl}}$ mice and causes only small changes in the number of OSNs. The average decrease in Lhx2 mRNA in samples of olfactory mucosae from OmpCre:Lhx $2^{f / f l}$ mice is $16 \%(p=0.002613, n=4)$. The average abundance of 697 immature OSN-specific mRNAs in OmpCre:Lhx $2^{f / / f l}$ mice is $1.06 \pm 0.13$-fold that of littermate controls, indicating that the numbers of immature OSNs are normal or perhaps slightly elevated. The average abundance of 581 mature OSN-specific mRNAs
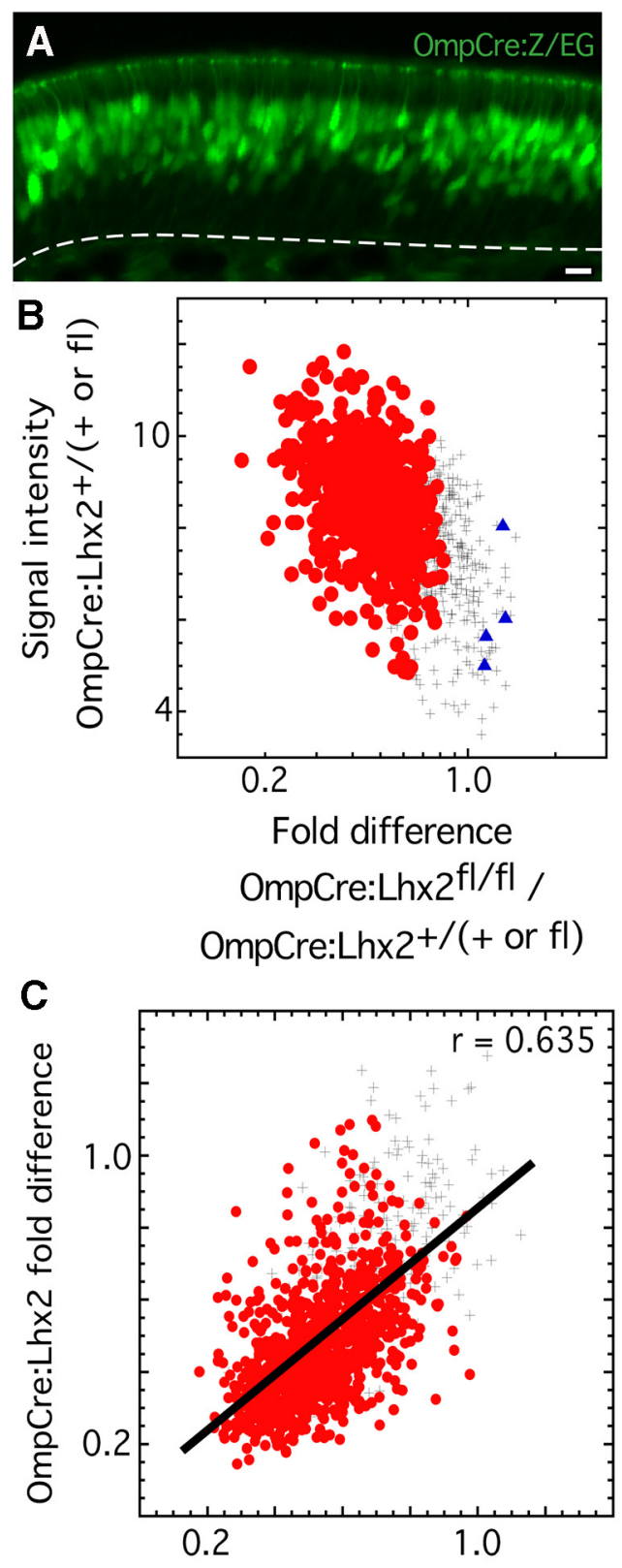

123Cre:Lhx2 fold difference

Figure 4. Deletion of $L h x 2$ in mature OSNs decreases the abundance of most OR mRNAs. $\boldsymbol{A}$, In OmpCre:Z/EG mice, recombination-dependent GFP expression marks OSNs in the mature OSN layer. Dashed line, Location of the basal lamina separating the olfactory epithelium and lamina propria. Scale bar, $20 \mu \mathrm{m}$. B, In OmpCre:Lhx2 ${ }^{\mathrm{fl} / \mathrm{fl}}$ mice, the abundance of 765 OR mRNAs is decreased relative to littermate controls $(p<0.01$; $n=4$; FDR $<1 \%)$. $\bullet$, Significant decrease; + , no difference from littermate controls; $\Delta$, increased abundance. C, Deletion of $L h x 2$ in immature OSNs (123Cre:Lhx2) and mature OSNs (OmpCre: Lhx2) produced similar effects on the abundance of most OR mRNAs relative to littermate controls. Line, Pearson linear correlation fit; $\bullet$, significant decrease in at least one of the two datasets; + , no decrease compared with littermate controls.

is reduced $12 \%$ on average compared with littermate controls, indicating a small reduction in the number of mature OSNs. Just as in 123Cre:Lhx $2^{\mathrm{fl} / \mathrm{fl}}$ mice, OmpCre: 


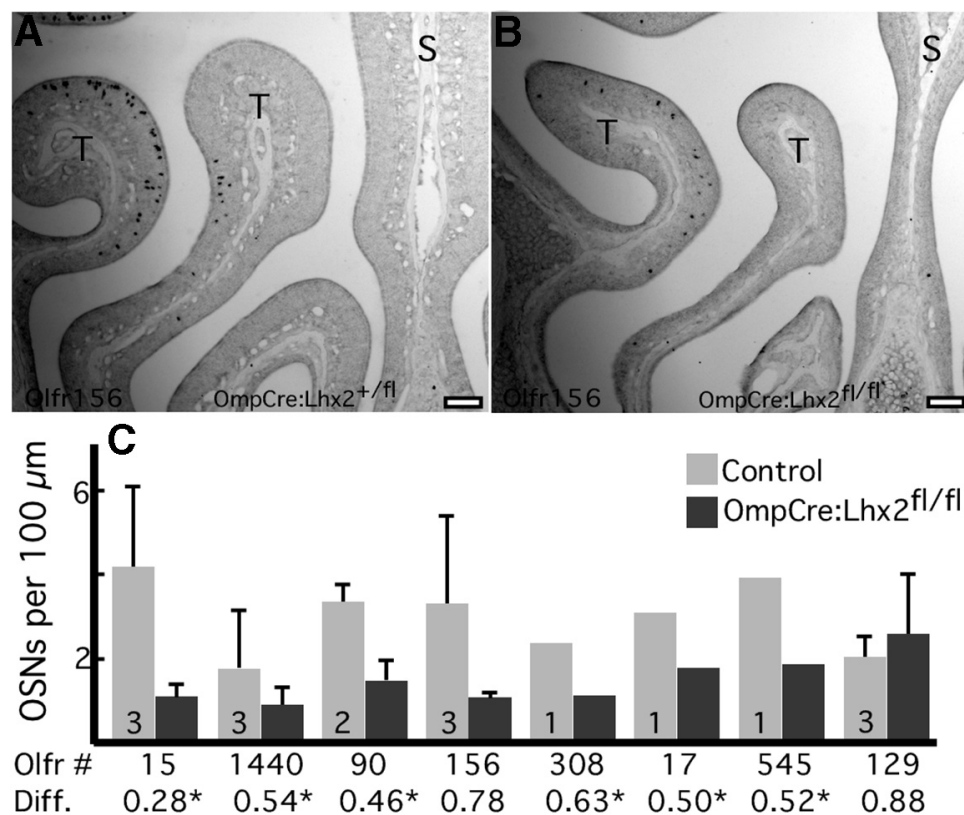

Figure 5. Conditional deletion of $L h x 2$ in mature OSNs reduces OR expression frequencies. $\boldsymbol{A}$, In situ hybridization shows that Olfr156 is expressed in scattered OSNs in the ventral olfactory epithelium. $\boldsymbol{B}$, In OmpCre:Lhx2 $2^{\mathrm{fl} / \mathrm{fl}}$ mice, the frequency of OSNs expressing Olfr156 is reduced. $\boldsymbol{C}$, Normalized cell counts from in situ hybridization images show that the ORs tested are less frequently expressed in OmpCre:Lhx2 $2^{\mathrm{fl} / f \mathrm{l}}$ mice compared with littermate controls, which is in agreement with normalized fold differences (Diff.) measured in the microarray experiment. *Significant difference $(p<0.01 ; n=4$; FDR $<1 \%)$. T, Turbinate; S, nasal septum. Scale bars, $100 \mu \mathrm{m}$.

Lhx $2^{\mathrm{fl} / \mathrm{fl}}$ mice show no evidence of increased OSN turnover. We find no difference in the frequency of active Casp3-immunoreactive cells in the olfactory epithelia of these mice ( $p=0.2473, n=3$ mice).

Even though Lhx2 is not lost until OSNs reach maturity in OmpCre:Lhx2 $2^{\mathrm{fl} / \mathrm{fl}}$ mice, the effects on OR and TAAR mRNAs are as widespread as in 123Cre:Lhx2 ${ }^{\mathrm{fl} / \mathrm{fl}}$ mice (Fig. $4 B)$. After normalizing to $12 \%$ fewer mature OSNs, we detect decreased abundance of 765 OR mRNAs and 12 TAAR mRNAs ( $p<0.01 ; n=4$; FDR $<1 \%$ ). The significantly reduced TAAR mRNAs are Taar2, Taar3, Taar4, Taar5, Taar6, Taar7a, 7b, 7d, 7e, 7f, Taar8a, and Taar9. In addition, four OR mRNAs show significant increases in abundance. In order of decreasing fold difference, they are as follows: Olfr1465, Olfr401, Olfr574, and Olfr1462.

The similarity of effects on OR mRNA abundance in OmpCre:Lhx $2^{\mathrm{fl} / \mathrm{fl}}$ mice and 123Cre:Lhx2 $2^{\mathrm{fl} / \mathrm{fl}}$ mice suggests that Lhx2 is acting consistently on OR gene control elements at both stages of OSN differentiation. If so, the same ORs should be affected in both conditional deletion strains. This proves correct, with 530 OR mRNAs showing significant decreases in both 123Cre:Lhx $2^{\mathrm{fl} / \mathrm{fl}}$ mice and OmpCre:Lhx $2^{\mathrm{fl} / \mathrm{fl}}$ mice. Not only are the same ORs affected, the majority of ORs tend to show similar fold differences in abundance in OmpCre:Lhx $2^{\mathrm{fl} / \mathrm{fl}}$ mice and 123Cre:Lhx ${ }^{\mathrm{fl} / \mathrm{fl}}$ mice (Fig. 4C). The average reduction in OR mRNA abundance in OmpCre:Lhx $2^{\mathrm{fl} / \mathrm{fl}}$ mice is $41 \%$ after normalization. For ORs that reach significance, the average reduction is $53 \%$.

Just as in 123Cre:Lhx2 $2^{\mathrm{fl} / \mathrm{fl}}$ mice, the decreased abundance of OR mRNAs in OmpCre:Lhx2 $2^{\mathrm{fl} / \mathrm{fl}}$ mice is associated with decreased frequencies of expression of these
ORs (Fig. 5), an effect that is not due to increased latencies for signal development during in situ hybridization. The four OR mRNAs that increase in abundance are more difficult to assess because they have very low expression frequencies. For example, in situ hybridization for Olfr1465, which shows the largest increase at 1.3-fold, detects fewer than one labeled cell per tissue section. Counts of labeled cells reveal no difference between $L h x 2$ conditional deletion mice and controls $(p=$ $0.3152 ; n=3$ mice), with OmpCre:Lhx $2^{\text {fl/fl }}$ mice at $0.42 \pm$ 0.38 cells per tissue section and littermate controls at 0.66 \pm 0.70 cells per tissue section.

\section{Emx2 deletion in OSNs has small effects on OR expression}

OR expression is not completely lost after conditional deletion of $L h x 2$ in OSNs. Incomplete deletion of $L h x 2$ across the population of OSNs must be responsible for much of the continued expression of ORs, but contributions from other mechanisms are also possible. For example, other transcription factors might substitute for Lhx2 or may be sufficient in some cases to drive OR gene transcription by themselves. Among homeodomain transcription factors that could substitute for Lhx2, the most promising candidate is Emx2. Like Lhx2, Emx2 was captured in a yeast one-hybrid assay using an OR promoter sequence (Hirota and Mombaerts, 2004). Embryonic mice with a germ-line deletion of Emx2 show altered abundance of many OR mRNAs due to altered expression frequencies (Mclntyre et al., 2008). Reassessing these data using the normalization procedure applied to our conditional Lhx2 mutant data, 159 OR mRNAs are signif- 
Table 3. OR mRNAs significantly affected in conditional Emx2 deletion mutants

\begin{tabular}{|c|c|c|}
\hline Gene symbol & $\begin{array}{l}\text { 123Cre:Emx2 } \\
\text { fold difference }\end{array}$ & $\begin{array}{l}\text { OmpCre:Emx2 } \\
\text { fold difference }\end{array}$ \\
\hline Olfr1087 & $0.5583 *$ & 0.7984 \\
\hline Olfr11 & 0.7444 & $0.7893 *$ \\
\hline Olfr111 & $0.6708 *$ & 0.7826 \\
\hline Olfr12 & 1.0522 & $0.8621 *$ \\
\hline Olfr1249 & 0.7437 & $0.7533 *$ \\
\hline Olfr1277 & 1.1381 & $0.6814 *$ \\
\hline Olfr130 & 0.9735 & $0.8090 *$ \\
\hline Olfr1309 & 0.9657 & $0.7151 *$ \\
\hline Olfr1325 & 0.4873 & 0.6895* \\
\hline Olfr1355 & $0.6195 *$ & 0.7902 \\
\hline Olfr1359 & 0.5582 & $0.4949 *$ \\
\hline Olfr1364 & 0.7881 & $0.7082 *$ \\
\hline Olfr1419 & $0.6804 *$ & $0.7846 *$ \\
\hline Olfr1424 & $0.5759 *$ & $0.6292 *$ \\
\hline Olfr1425 & 0.8455 & 0.7678 \\
\hline Olfr144 & $1.8484 *$ & 0.9650 \\
\hline Olfr1457 & 0.8257 & $0.7559 *$ \\
\hline Olfr1495 & $0.6704 *$ & 1.0229 \\
\hline Olfr15 & $1.6782 *$ & 1.1469 \\
\hline Olfr214 & $1.7787 *$ & 0.8971 \\
\hline Olfr222 & $0.6071 *$ & $0.6777 *$ \\
\hline Olfr270 & $0.4249 *$ & 0.8188 \\
\hline Olfr283 & $0.8051 *$ & 0.8693 \\
\hline Olfr291 & $0.6210 *$ & 0.8153 \\
\hline Olfr298 & 0.3893 & $0.5313 *$ \\
\hline Olfr335 & $1.1136 *$ & 1.0004 \\
\hline Olfr361 & 0.7965 & $0.7296 *$ \\
\hline Olfr42 & 0.8677 & $0.5843 *$ \\
\hline Olfr523 & $0.8668 *$ & 0.8304 \\
\hline Olfr71 & 0.7472 & $0.8246 *$ \\
\hline Olfr801 & $0.4410 *$ & 0.8148 \\
\hline Olfr90 & $1.6394 *$ & 1.0124 \\
\hline Olfr91 & $1.3067 *$ & 0.8880 \\
\hline Olfr99 & $0.6356 *$ & 0.8504 \\
\hline
\end{tabular}

*Significant difference.

icantly decreased, and 52 are increased in the germ-line Emx2 deletion ( $p<0.05$; FDR $<10 \%$ ). We tested whether delaying the deletion of Emx2 until the OSN cell lineage reaches the OSN stages would have similar effects by breeding 123Cre:Emx2 $2^{\mathrm{fl} / \mathrm{fl}}$ mice and OmpCre:Emx2 $2^{\mathrm{fl} / \mathrm{fl}}$ mice.

In both strains, the Emx2 gene locus is successfully recombined. In 123Cre:Emx $2^{\text {fl/fl }}$ mice, Emx2 mRNA is reduced by $48 \%(p=0.00001 ; n=4)$. In OmpCre:Emx2 $2^{\mathrm{f} / \mathrm{fl}}$ mice, Emx2 mRNA is decreased $32 \%(p=0.00059 ; n=$ 4). Lhx2 mRNA abundance is not affected in either 123Cre:Emx2 ${ }^{\mathrm{fl} / \mathrm{fl}}$ mice (fold difference, 0.99, $p=0.9343$; $n=4$ ) or OmpCre:Emx2 $2^{\mathrm{fl} / \mathrm{fl}}$ mice (fold difference, 1.03, $p=$ $0.6205 ; n=4)$. Unlike germ-line deletion of $E m \times 2$, the numbers of mature and immature OSNs are unaffected after conditional Emx2 deletion.

OR mRNA abundance is only mildly affected by conditional deletion of Emx2 in OSNs. Only 34 OR mRNAs show $p<0.01$ in these experiments (Table 3 ), and none of these have an FDR of $<1 \%$. In 123Cre:Emx2 $2^{\mathrm{flfl}}$ mice, 6 of these 34 OR mRNAs increase in abundance, but these same mRNAs are not significantly more abundant in OmpCre:Emx $2^{\mathrm{fl} / \mathrm{fl}}$ mice. The values in Table 3 suggest that the magnitude of the effects of Emx2 deletion differ between the two strains, a hypothesis that proves true. The average absolute value of the fold difference in 123Cre: $\mathrm{Em} \times 2^{\mathrm{t} / \mathrm{fl}}$ mice compared with littermate controls is $0.34 \pm$ 0.21 , compared with $0.21 \pm 0.12$ for OmpCre:Emx $2^{\mathrm{fl} / \mathrm{fl}}$ mice ( $p=0.0064, n=4$; two-tailed paired $t$ test). The ability of Emx2 to impact OR expression appears to decrease with OSN maturation.

Only 3 of these 34 OR mRNAs are significantly decreased in both conditional Emx2 deletion strains. In addition, most of these 34 ORs are not specifically dependent on Emx2. Only six of them are not significantly decreased after the deletion of $L h x 2$ in either immature or mature OSNs (Olfr11, Olfr71, Olfr111, Olfr270, Olfr1249, and Olfr1457).

\section{Additive effect of conditional deletion of both Lhx2 and $E m \times 2$}

Given that OR gene expression is sensitive to Lhx2 and to Emx2, the simultaneous loss of both might reveal epistasis or compensatory effects. To test this hypothesis, we generated 123Cre:Lhx2 $2^{\mathrm{fl} / \mathrm{fl}:} \mathrm{Em \times 2} 2^{\mathrm{fl} / \mathrm{fl}}$ mice.

In 123Cre:Lhx2 $2^{\mathrm{fl} / \mathrm{fl}:}: \mathrm{Em} \times 2^{\mathrm{fl} / \mathrm{fl}}$ mice, Emx2 mRNA is decreased by $57 \%(p=0.0005 ; n=4)$ and Lhx2 mRNA is decreased by $27 \%(p=0.0005 ; n=4)$. Immature OSNspecific mRNAs show a small increase on average, a fold difference of $1.11 \pm 0.20 \%$ ( $n=4$ mice), arguing that the immature OSN number may be slightly increased. Mature OSN-specific mRNAs show a small decrease, an average fold difference of $74 \pm 25 \%$ ( $n=4$ mice). Just as with the other conditional deletion strains tested, this decrease in the number of mature OSNs is not associated with detectably increased OSN turnover. The frequency of active Casp3-immunoreactive cells in the olfactory epithelia of 123Cre:Lhx $2^{f / f f l}: E m \times 2^{f / / f l}$ mice is not different from that of littermate controls $(p=0.5271 ; n=3)$.

Fewer than 700 OR mRNAs meet our criteria for significant differences after the loss of either Lhx2 or Emx2 at the immature OSN stage. The loss of both homeodomain transcription factors at this stage reduces the abundance of 755 OR mRNAs and increases the abundance of 10 others (Fig. 6). This is not much more than an additive effect, arguing that Lhx2 and Emx2 lack epistasis and do not compensate for each other.

Among the Taar mRNAs, Taar2, Taar3, Taar4, Taar5, Taar6, Taar7a, 7b, 7d, 7e, 7f, and Taar9 are decreased. Only the mRNAs of the members of the Taar8 subfamily are not significantly affected.

As in all other mutant strains we tested, changes in OR

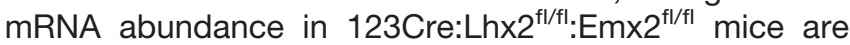
due to changes in the frequency of OR gene expression (Fig. 7). Even some OR genes whose mRNAs did not reach significance in the microarray experiment, such as Olfr156, tend to show reduced frequencies of expression (Fig. 7C). OR genes that increase in expression frequency in Emx2-null mice, such as Olfr90 and Olfr15 (McIntyre et al., 2008), show reduced expression frequency when both Lhx2 and Emx2 are absent. These findings reinforce the conclusion that OR gene expression depends more directly and strongly on Lhx2 than Emx2. 


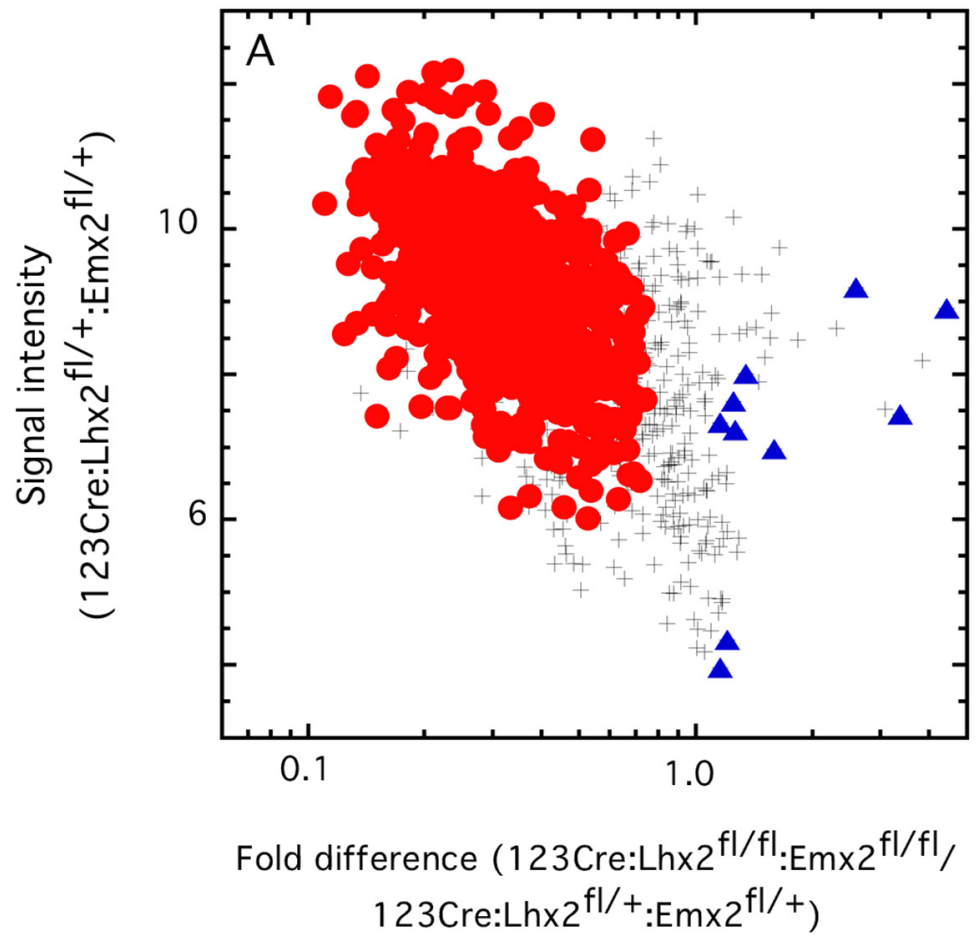

Figure 6. Conditional deletion of both $L h x 2$ and $E m \times 2$ in immature OSNs decreases the abundance of 755 OR mRNAs and increases the abundance of 10 OR mRNAs. $\bullet$, Significant decrease; +, no difference from littermate controls; $\mathbf{\Delta}$, increased abundance.

\section{Zonal expansion suggests different roles for Lhx2 and Emx2}

Conditional deletion of Lhx2 or Emx2 in OSNs almost never has effects on the zonal expression of ORs. In situ hybridization data for $11 \mathrm{OR}$ mRNAs showed a shift in the zonal pattern in only one OR gene, Olfr15. We previously demonstrated that Olfr15 mRNA increases in embryos with germ-line deletions of Emx2 (Mclntyre et al., 2008). The increase is mostly due to increased expression frequency within the normal ventral expression zone of Olfr15, but the expansion of expression into the dorsal OR expression zone of the olfactory epithelium also contributes. We find this zonal expansion effect in all the conditional Emx2 deletion strains tested. We note that Olfr15 may be unusually susceptible to zonal misexpression. Across several dozen tissue sections from control littermates, we have observed three instances where a single dorsal zone OSN misexpresses Olfr15. The image shown in Figure $8 \mathrm{C}$ was chosen to illustrate one of these three instances.

In contrast to the increase in Olfr15 expression frequency in both ventral and dorsal regions of the olfactory epithelium after the deletion of $E m \times 2$, when $L h \times 2$ is deleted in either immature or mature OSNs, Olfr15 expression frequency is reduced (Fig. $8 A, B$ ). Olfr 15 mRNA is also decreased when both $L h \times 2$ and $E m \times 2$ are deleted, but in situ hybridization data reveal that this overall decrease obscures a zone-specific increase in Olfr15 expression. In these double mutants, Olfr15 expression is indeed decreased within its normal ventral expression zone, but the expansion of Olfr15 expression into the dorsal zone that results from the loss of Emx2 is also apparent (Fig. $8 C, D$ ).
These findings suggest that Lhx2 and Emx2 play distinctly different roles in controlling OR expression, at least for some ORs. The absence of Lhx2 makes Olfr15 less likely to be expressed, the same effect that the absence of Lhx2 has on other ORs. In contrast, the absence of Emx2 makes Olfr15 more likely to be expressed, as if Emx2 helps to control the availability of Olfr15 for expression.

\section{OSN turnover is unchanged in conditional $L h \times 2$ deletion mutants}

Small reductions in mature OSN numbers accompany the reduced frequency of OR expression when $L h \times 2$ is deleted in OSNs, a finding that could indicate an alternative cause for altered OR expression. Increased turnover of OSNs could disrupt normal OSN development and lead to altered OR expression frequencies, similar to the effects seen at long survival times after unilateral naris occlusion or when olfactory neurogenesis is disrupted (Coppola and Waggener, 2012; Zhao et al., 2013). However, none of the strains show an increase in the frequency of cells immunoreactive for activated Casp3 (Fig. $9 A, B)$. This evidence of normal OSN turnover is also supported by the lack of difference in the frequency of mitosis among basal cells (phosphorylated histone $3 \mathrm{im}$ munoreactivity; Fig. 9C,D). Basal cell mitosis would increase if OSN turnover increased as tissue homeostasis mechanisms attempt to maintain normal numbers of OSNs. As is typical for juvenile mice reared in modern barrier housing facilities, most tissue sections show no cells immunoreactive for phosphorylated histone 3. Occasional sections show one or two dividing cells, and even more rare are sections with small clusters of dividing 

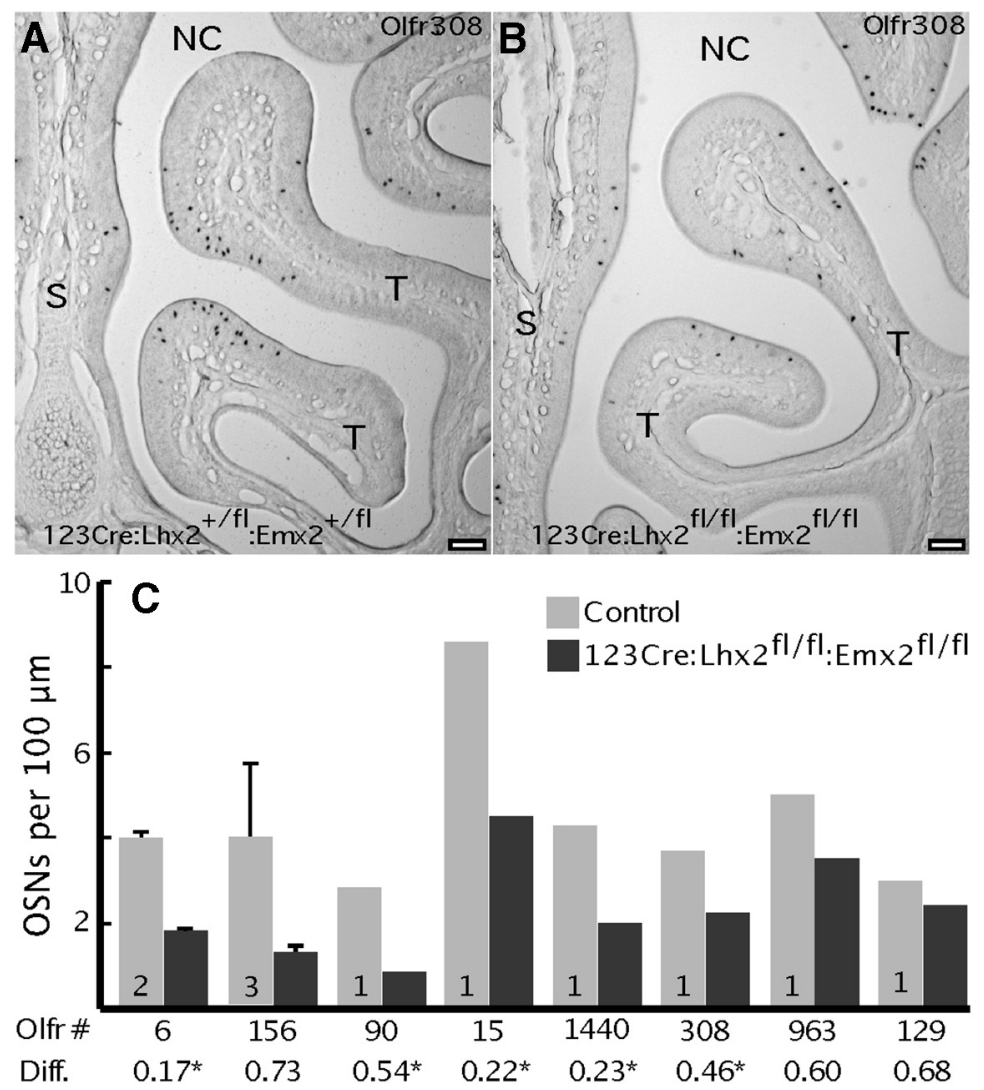

Figure 7. Conditional deletion of both $L h x 2$ and $E m \times 2$ in immature OSNs reduces OR expression frequencies. $\boldsymbol{A}$, In situ hybridization shows that Olfr308 is expressed in scattered OSNs in the ventral olfactory epithelium. $\boldsymbol{B}, \operatorname{In} 123 \mathrm{Cre}: \mathrm{Lh} \times 2^{\mathrm{fl} / \mathrm{fl} l}: \mathrm{Em \times 2} \mathrm{fl}^{\mathrm{fl} / \mathrm{fl}} \mathrm{mice}$, the frequency of OSNs expressing Olfr308 appears to be reduced. NC, Air space of the nasal cavity; S, nasal septum; T, turbinate. Scale bars, $100 \mu \mathrm{m}$. C, Normalized cell counts from in situ hybridization images show that ORs are less frequently expressed in

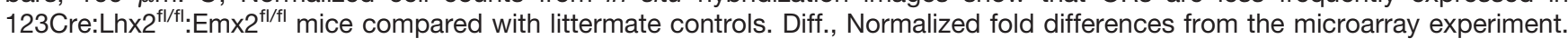
*Significant difference (p 0.01; n 4; FDR 1\%).

cells. The latter makes for substantial variation in cell counts. For example, the large difference in average counts between null mutants and littermate controls in 123Cre:Lhx2 mice (Fig. 9D) does not reach significance after correction for multiple testing $(q=0.3525 ; n=3$ mice).

Additional supporting evidence is the absence of an increase in CD68-immunoreactive macrophages in the olfactory epithelium (Fig. 9E,F). Macrophages respond to increased OSN turnover in order to help clear cell debris from the olfactory epithelium (Suzuki et al., 1995; Blomster et al., 2011; Heron et al., 2013).

In none of the five conditional deletion strains that we bred do we observe reduced numbers of immature OSNs. Instead, the absence of Lhx2 tends to cause small increases in immature OSNs in juvenile mice, contributing to a negative correlation between the numbers of mature and immature OSNs $(r=0.86)$. This is distinctly different from germ-line deletion of $L h x 2$, where both mature and immature OSNs are reduced (Kolterud et al., 2004). Overall, our data suggest that conditional deletion of $L h x 2$ in OSNs leads to olfactory epithelia that have a slightly altered balance between numbers of immature and mature OSNs, but no detectable change in OSN turnover.

\section{Discussion}

We assessed the effects of conditional deletion in OSNs of $L h \times 2$ and Emx2 on OR expression. Unlike previous strategies that cause the loss of essentially all mature OSNs in Lhx2 mutant mice (Hirota et al., 2007; Berghard et al., 2012), our strategy results in nearly normal numbers of OSNs, allowing us to reliably measure effects of the absence of Lhx2 on OR gene expression. We find that OR expression depends greatly upon Lhx2, and to a much lesser extent upon Emx2. Deleting Lhx2 after OSN maturation is equivalent to the deletion of $L h x 2$ that begins in immature OSNs, arguing that Lhx2 has the same role in regulating $\mathrm{OR}$ expression in both mature and immature OSNs. Emx2 may help to drive OR expression just like Lhx2, but it also has a distinctly different role that may involve controlling the availability of some OR genes for expression.

\section{Nearly all ORs and TAARs depend on Lhx2}

All three conditional $L h x 2$ deletion strains show the same effect, large decreases in the abundance of OR mRNAs far beyond what can be explained by small reductions in the number of mature OSNs. At the cellular level, this manifests as altered frequencies of $\mathrm{OR}$ expression. 

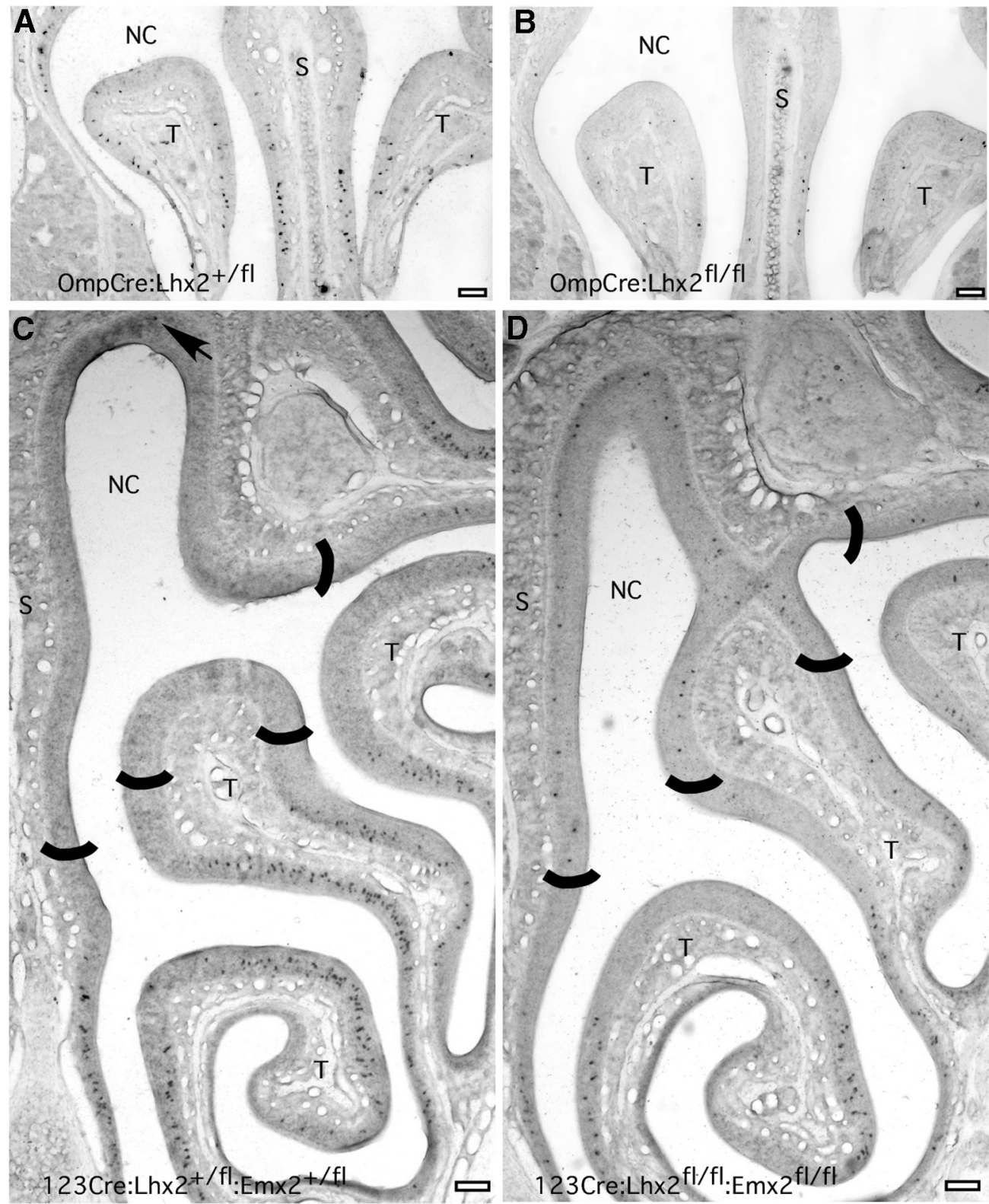

Figure 8. The absence of Lhx2 and the absence of Emx2 have distinctly different effects on Olfr15 expression frequency. $\boldsymbol{A}$, In situ hybridization image showing normal Olfr15 expression in the ventral region of the olfactory epithelium in a littermate control. $\boldsymbol{B}$, When Lhx2 is deleted in OSNs, Olfr15 expression frequency decreases. $\boldsymbol{C}$, An image of the left half of a more caudal section from a littermate control shows the normal expression of Olfr15 in the ventral olfactory epithelium. This image shows one of the rare instances of the misexpression of Olfr15 in the dorsal olfactory epithelium in control genotypes (arrow). $\boldsymbol{D}$, When both Lhx2 and Emx2 are deleted, Olfr15 expression frequency decreases in the ventral region, where it is normally expressed, but misexpression increases in the dorsal region. The approximate boundaries between dorsal and ventral olfactory epithelium are marked in $\boldsymbol{C}$ and $\boldsymbol{D}$. NC, Air space of the nasal cavity; S, nasal septum; T, turbinate. Scale bars, $100 \mu \mathrm{m}$.

Of the 1098 mRNAs encoding functional ORs that we measured, 965 are significantly decreased in at least one conditional $L h x 2$ deletion strain. If we also include those OR mRNAs that displayed a tendency to differ $(0.01>p$ $<0.05)$, then only 44 OR mRNAs are consistently unaffected by the loss of Lhx2. Consistent with a critical role for Lhx2 in the expression of ORs, the ORs insensitive to the loss of Lhx2 tend to be expressed at low frequencies.

Loss of Lhx2 has similarly broad effects on TAAR gene expression. The mRNAs of all 13 functional TAAR genes expressed in OSNs are reduced in 123Cre:Lhx2 $2^{\mathrm{fl} / \mathrm{fl}}$ mice, OmpCre:Lhx2 $2^{\mathrm{f} / \mathrm{fl}}$ mice, or both (but note that this is a tentative conclusion for Taar8a due to ambiguity in the probe set used to detect it). These data predict that TAAR genes have homeodomain sites in their enhancers, promoters, or both.

Importantly, the Lhx2 dependence of OR gene expression is almost certainly a direct effect. Lhx2 binds OR gene promoters and enhancers (Hoppe et al., 2003; Hirota and Mombaerts, 2004; Markenscoff-Papadimitriou et al., 

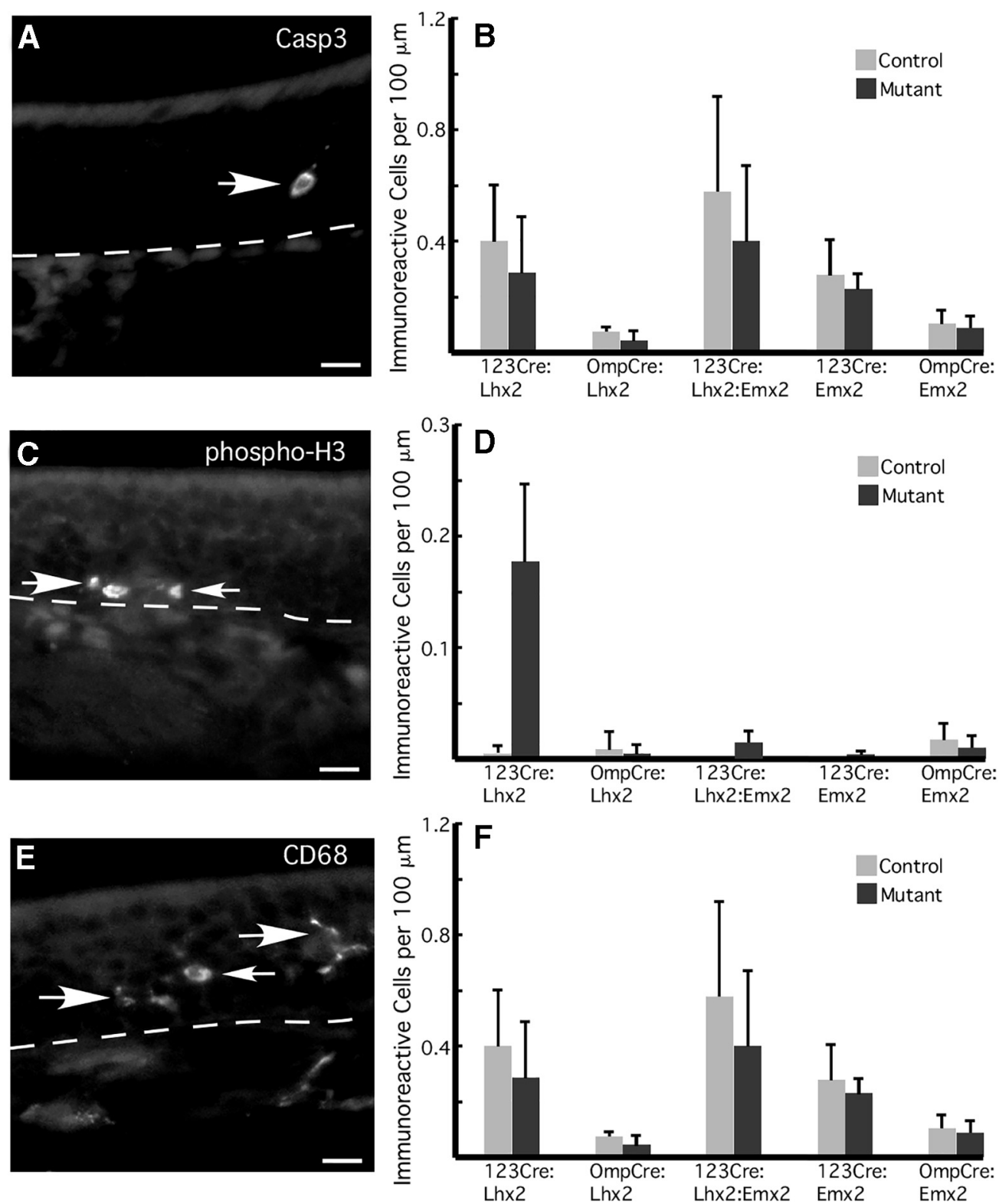

Figure 9. OSN turnover in Lhx2 and Emx2 mutant mice is indistinguishable from that of littermate controls. $\boldsymbol{A}$, Image of active caspase 3 immunoreactivity showing a cell undergoing apoptosis in the OSN layer of the olfactory epithelium (arrow). $\boldsymbol{B}$, Counts of the number of active caspase 3 immunoreactive OSNs reveal no significant differences between mutant mice and control littermates $(n=3$ mice). C, Phosphorylated histone 3 (phospho-H3) immunoreactivity in the basal cell layer identifies basal cells undergoing mitosis (arrows). $\boldsymbol{D}$, Quantification of phosphorylated histone 3 immunoreactive basal cells shows no significant differences between mutant mice and control littermates ( $n=3$ mice). $\boldsymbol{E}$, CD68 immunoreactivity identifies activated macrophages (arrows). F, Quantification of CD68immunoreactive macrophages in the olfactory epithelium reveals no significant differences between mutant mice and control littermates $(n=3$ mice). Dashed lines, Location of the basal lamina. Scale bars, $50 \mu \mathrm{m}$.

2014). Our data provide no evidence for indirect effects, such as the reduced expression of other transcription factors, nor does the conditional deletion of $L h x 2$ lead to a loss or turnover of OSNs that is sufficient to explain the strength and breadth of the effects observed. We conclude that Lhx2 is the transcription factor that acts at the homeodomain sites in the enhancers and proximal promoters of OR genes, and that nearly all OR genes require Lhx2 for expression.

Neither 123Cre nor OmpCre are able to recombine a Z/EG transgene or the native Lhx2 locus at $100 \%$ effi- ciency, so OSNs expressing Lhx2-dependent OR genes in the conditional deletion Lhx2 mouse strains are mostly OSNs that continue to express Lhx2. We have not been able to directly identify OSNs that fail to express both Lhx2 and an OR or TAAR in these mutants, but because reductions in OR mRNA abundance far exceed the small reductions in mature OSN number, this must be the case. Given evidence that responding to odors and making the appropriate synaptic connections increases OSN lifespan (Schwob et al., 1992; Watt et al., 2004; Zhao et al., 2013), failure of $\mathrm{OR}$ expression should eventually reduce mature 
OSN numbers, consistent with our observation of fewer mature OSNs in Lhx2 conditional deletion mice. The alternative explanation that haploinsufficiency of Lhx2 contributes to the effects we observe is not plausible because Lhx2 heterozygotes expressing Cre do not show altered OR expression.

\section{Emx2 acts differently than Lhx2}

In comparison with Lhx2, Emx2 is necessary for the normal expression of a much smaller fraction of OR genes, and $E m \times 2$ deletion more often allows increased frequencies of OR expression; about $20-30 \%$ of the significantly affected OR mRNAs. In addition, the effects of deleting Emx2 are greater in immature OSNs than in mature OSNs, which is not true of the Lhx2 mutant strains. When both $L h \times 2$ and $E m \times 2$ are conditionally deleted in immature OSNs, no epistasis or compensatory effects are unmasked. These findings suggest that Lhx2 and Emx2 act mostly through independent mechanisms, an interpretation supported by the behavior of Olfr15. Olfr15 expression frequency specifically decreases in the absence of Lhx2, while zonal misexpression of Olfr15 is specific to the absence of Emx2. We cannot exclude the possibility that Emx2 acts like Lhx2 in driving the expression of some OR genes; but, if so, our data suggest that Emx2 also has a distinctly different role. We hypothesize that Emx2 helps to control the availability of OR genes for expression.

\section{OR expression in mature OSNs versus immature OSNs}

By the time an OSN reaches maturity, it strongly expresses a single allele of one OR gene. Repressive chromatin modification might prevent the expression of any other OR allele, predicting that no OR genes should increase their expression in OmpCre:Lhx2 $2^{\mathrm{fl} / \mathrm{fl}}$ mice. This seems inconsistent with our finding of 4 OR mRNAs that show significant increases and 56 additional OR mRNAs that show normalized fold differences of $>1$. At present, we are unable to rule out the possibility that mature OSNs can switch to a different OR allele (Shykind et al., 2004) if they lose the expression of their original OR allele. The small number and modest size of increases in OR expression could be explained by the rarity of opportunities for OR gene switching in OSNs lacking Lhx2, which are limited because nearly all OR genes depend on Lhx2 for expression. Another factor that could contribute to the limited opportunity for OR gene switching is the relative timing of OR gene choice and Cre recombination. The timing of OR gene choice is not yet firmly established, so it is possible that choice happens prior to the onset of Cre expression in immature OSNs in 123Cre:Lhx ${ }^{\mathrm{fl} / \mathrm{fl}}$ mice. If true, this would explain the similar OR expression patterns between 123Cre:Lhx2//fl mice and OmpCre:Lhx2 ${ }^{\mathrm{fl} / \mathrm{fl}}$ mice.

Opportunities for differential survival of OSNs to cause increased frequency of expression of some ORs are limited because OSN turnover is not significantly elevated. However, we note that significant increases in the abundance of some Lhx2-independent OR mRNAs are detected at age P26 (OmpCre:Lhx2 $2^{\mathrm{fl} / \mathrm{fl}}$ mice and 123Cre: Lhx2 $2^{\mathrm{f} / \mathrm{fl}:}: \mathrm{Emx} 2^{\mathrm{fl} / \mathrm{fl}}$ mice) but not at age P3 (123Cre:Lhx2 $2^{\mathrm{fl} / \mathrm{fl}}$ mice), so it may be possible that better survival gradually leads to increased frequencies of OSNs that express Lhx2-independent ORs.

\section{Effects of altered OR expression on OSN maturation}

Our data agree with previous evidence that the absence of Lhx2 slows immature OSN differentiation and even prevents the transition to the mature OSN stage (Berghard et al., 2012). Given that OSN turnover is not detectably altered in our conditional $L h x 2$ deletion strains, differences in OSN maturation may contribute to differences in the numbers of OSNs present. In neonatal 123Cre:Lhx $2^{\mathrm{fl} / \mathrm{fl}}$ mice, the numbers of mature OSNs are reduced slightly, while immature OSN numbers do not differ, which is consistent with the idea that immature OSNs are not producing mature OSNs as fast as their littermate controls. Because conditional deletion of $E m \times 2$ does not affect OSN number, the slightly decreased numbers of mature OSNs and slightly increased numbers of immature OSNs in juvenile 123Cre:Lhx $2^{\mathrm{fl} / \mathrm{fl}}: \mathrm{Em} \times 2^{\mathrm{fl} / \mathrm{fl}}$ mice must also be due to the absence of Lhx2. Immature OSN differentiation appears to be slowed in the absence of Lhx2, causing immature OSN numbers to build up postnatally. We conclude that the absence of Lhx2 halts OSN maturation by causing OR expression to fail, thereby preventing the feedback signaling that stabilizes the expression of a single OR allele and triggers the final maturation of the OSN (Dalton et al., 2013).

\section{The role of Lhx2 in OR gene choice}

We find no evidence that Lhx2 is necessary for the zonal patterns of OR expression, nor for the singularity of OR expression per OSN. Instead, Lhx2 is necessary to drive OR expression. We envision two speculative models for Lhx2 action that are consistent with our data, one where Lhx2 has a direct role in OR gene choice, another where Lhx2 acts indirectly.

The ability of Lhx2 to bind OR enhancers, along with the evidence that OR enhancers form interchromosomal networks, raises the possibility that differing enhancer networks might determine which OR alleles become expressed (Markenscoff-Papadimitriou et al., 2014). Because Lhx2 binds these enhancers, Lhx2 is likely to help determine which enhancer networks form or which OR gene promoters interact with these networks, effects that could explain the Lhx2 dependence of OR gene expression frequencies. In the absence of Lhx2, the probability of the formation of each distinct enhancer network should decrease, probably to differing extents. This would lead directly to the differentially decreased expression of OR genes that we observe.

Alternatively, Lhx2 might indirectly contribute to OR gene choice. Epigenetic repression and derepression of OR alleles in immature OSNs might be balanced so as to randomly produce a fully derepressed allele at rare intervals. The role of Lhx2 in this model is to drive high levels of OR transcription when an OR allele becomes available, triggering the feedback that prevents the expression of any other OR allele. If OR genes differ in the degree to which their transcription depends on Lhx2 relative to other transcriptional regulators, then those OR genes that are 
most dependent on Lhx2 would have the lowest probability of becoming stably expressed and the most difficulty maintaining feedback repression in mature OSNs. This model would also result in the kinds of differences in OR expression frequency that we observe.

These two general models are not mutually exclusive and could both be active. They both explain how OR expression frequencies could have a fundamental randomness yet depend so strongly on Lhx2, even after OSNs have completed differentiation.

\section{References}

Baker H, Grillo M, Margolis FL (1989) Biochemical and immunocytochemical characterization of olfactory marker protein in the rodent central nervous system. J Comp Neurol 285:246-261. CrossRef Medline

Benjamini Y, Hochberg Y (1995) Controlling the False Discovery Rate: a practical and powerful approach to multiple testing. J R Stat Soc Series B Stat Methodol 57:289-300.

Berghard A, Hägglund AC, Bohm S, Carlsson L (2012) Lhx2dependent specification of olfactory sensory neurons is required for successful integration of olfactory, vomeronasal, and $\mathrm{GnRH}$ neurons. FASEB J 26:3464-3472. CrossRef Medline

Blomster LV, Vukovic J, Hendrickx DA, Jung S, Harvey AR, Filgueira L, Ruitenberg MJ (2011) CX ${ }_{3}$ CR1 deficiency exacerbates neuronal loss and impairs early regenerative responses in the target-ablated olfactory epithelium. Mol Cell Neurosci 48:236-245. CrossRef Medline

Bozza T, Feinstein P, Zheng C, Mombaerts P (2002) Odorant receptor expression defines functional units in the mouse olfactory system. J Neurosci 22:3033-3043. Medline

Cheong JW, Chong SY, Kim JY, Eom JI, Jeung HK, Maeng HY, Lee ST, Min YH (2003) Induction of apoptosis by apicidin, a histone deacetylase inhibitor, via the activation of mitochondria-dependent caspase cascades in human Bcr-Abl-positive leukemia cells. Clin Cancer Res 9:5018-5027. Medline

Chou SJ, O'Leary DD (2013) Role for Lhx2 in corticogenesis through regulation of progenitor differentiation. Mol Cell Neurosci 56:1-9. CrossRef Medline

Chou SJ, Perez-Garcia CG, Kroll TT, O'Leary DD (2009) Lhx2 specifies regional fate in Emx1 lineage of telencephalic progenitors generating cerebral cortex. Nat Neurosci 12:1381-1389. CrossRef Medline

Clowney EJ, LeGros MA, Mosley CP, Clowney FG, MarkenskoffPapadimitriou EC, Myllys M, Barnea G, Larabell CA, Lomvardas S (2012) Nuclear aggregation of olfactory receptor genes governs their monogenic expression. Cell 151:724-737. CrossRef Medline

Coppola DM, Waggener CT (2012) The effects of unilateral naris occlusion on gene expression profiles in mouse olfactory mucosa. $\mathrm{J}$ Mol Neurosci 47:604-618. CrossRef Medline

Dalton RP, Lyons DB, Lomvardas S (2013) Co-opting the unfolded protein response to elicit olfactory receptor feedback. Cell 155: 321-332. CrossRef Medline

DeMaria S, Ngai J (2010) The cell biology of smell. J Cell Biol 191:443-452. CrossRef Medline

de Melo J, Zibetti C, Clark BS, Hwang W, Miranda-Angulo AL, Qian J, Blackshaw S (2016) Lhx2 is an essential factor for retinal gliogenesis and notch signaling. J Neurosci 36:2391-2405. CrossRef Medline

Dwyer ND, Manning DK, Moran JL, Mudbhary R, Fleming MS, Favero CB, Vock VM, O'Leary DD, Walsh CA, Beier DR (2011) A forward genetic screen with a thalamocortical axon reporter mouse yields novel neurodevelopment mutants and a distinct emx2 mutant phenotype. Neural Dev 6:3 CrossRef

Farbman Al, Margolis FL (1980) Olfactory marker protein during ontogeny: immunohistochemical localization. Dev Biol 74:205215. Medline
Fleischmann A, Shykind BM, Sosulski DL, Franks KM, Glinka ME, Mei DF, Sun Y, Kirkland J, Mendelsohn M, Albers MW, Axel R (2008) Mice with a "monoclonal nose": perturbations in an olfactory map impair odor discrimination. Neuron 60:1068-1081. CrossRef Medline

Fukuchi-Shimogori T, Grove EA (2003) Emx2 patterns the neocortex by regulating FGF positional signaling. Nat Neurosci 6:825-831. CrossRef Medline

Gordon PJ, Yun S, Clark AM, Monuki ES, Murtaugh LC, Levine EM (2013) Lhx2 balances progenitor maintenance with neurogenic output and promotes competence state progression in the developing retina. J Neurosci 33:12197-12207. CrossRef Medline

Hamasaki T, Leingärtner A, Ringstedt T, O'Leary DD (2004) EMX2 regulates sizes and positioning of the primary sensory and motor areas in neocortex by direct specification of cortical progenitors. Neuron 43:359-372. CrossRef Medline

Heron PM, Stromberg AJ, Breheny P, McClintock TS (2013) Molecular events in the cell types of the olfactory epithelium during adult neurogenesis. Mol Brain 6:49. CrossRef Medline

Hirota J, Mombaerts P (2004) The LIM-homeodomain protein Lhx2 is required for complete development of mouse olfactory sensory neurons. Proc Natl Acad Sci U S A 101:8751-8755. CrossRef Medline

Hirota J, Omura M, Mombaerts P (2007) Differential impact of Lhx2 deficiency on expression of class I and class II odorant receptor genes in mouse. Mol Cell Neurosci 34:679-688. CrossRef Medline

Hoppe R, Frank H, Breer H, Strotmann J (2003) The clustered olfactory receptor gene family 262 : genomic organization, promotor elements, and interacting transcription factors. Genome Res 13:2674-2685. CrossRef Medline

Hoppe R, Breer H, Strotmann J (2006) Promoter motifs of olfactory receptor genes expressed in distinct topographic patterns. Genomics 87:711-723. CrossRef Medline

Hsu LC, Nam S, Cui Y, Chang CP, Wang CF, Kuo HC, Touboul JD, Chou SJ (2015) Lhx2 regulates the timing of $\beta$-catenin-dependent cortical neurogenesis. Proc Natl Acad Sci U S A 112:1219912204. CrossRef Medline

Hu BR, Liu CL, Ouyang Y, Blomgren K, Siesjö BK (2000) Involvement of caspase-3 in cell death after hypoxia-ischemia declines during brain maturation. J Cereb Blood Flow Metab 20:1294-1300. CrossRef Medline

Inaki K, Nishimura S, Nakashiba T, Itohara S, Yoshihara Y (2004) Laminar organization of the developing lateral olfactory tract revealed by differential expression of cell recognition molecules. $J$ Comp Neurol 479:243-256. CrossRef Medline

Ishii T, Hirota J, Mombaerts P (2003) Combinatorial coexpression of neural and immune multigene families in mouse vomeronasal sensory neurons. Curr Biol 13:394-400. Medline

Ishii T, Omura M, Mombaerts P (2004) Protocols for two- and threecolor fluorescent RNA in situ hybridization of the main and accessory olfactory epithelia in mouse. J Neurocytol 33:657-669. CrossRef Medline

Johnson MA, Tsai L, Roy DS, Valenzuela DH, Mosley C, Magklara A, Lomvardas S, Liberles SD, Barnea G (2012) Neurons expressing trace amine-associated receptors project to discrete glomeruli and constitute an olfactory subsystem. Proc Natl Acad Sci U S A 109:13410-13415. CrossRef Medline

Kaiser CL, Chapman BJ, Guidi JL, Terry CE, Mangiardi DA, Cotanche DA (2008) Comparison of activated caspase detection methods in the gentamicin-treated chick cochlea. Hear Res 240:1-11. CrossRef Medline

Kolterud A, Alenius M, Carlsson L, Bohm S (2004) The Lim homeobox gene Lhx2 is required for olfactory sensory neuron identity. Development 131:5319-5326. CrossRef Medline

Koo JH, Saraswati M, Margolis FL (2005) Immunolocalization of Bex protein in the mouse brain and olfactory system. J Comp Neurol 487:1-14. CrossRef Medline

Li J, Ishii T, Feinstein P, Mombaerts P (2004) Odorant receptor gene choice is reset by nuclear transfer from mouse olfactory sensory neurons. Nature 428:393-399. CrossRef Medline 
Liberles SD, Buck LB (2006) A second class of chemosensory receptors in the olfactory epithelium. Nature 442:645-650. CrossRef Medline

Lyons DB, Lomvardas S (2014) Repressive histone methylation: a case study in deterministic versus stochastic gene regulation. Biochim Biophys Acta 1839:823-838.

Lyons DB, Allen WE, Goh T, Tsai L, Barnea G, Lomvardas S (2013) An epigenetic trap stabilizes singular olfactory receptor expression. Cell 154:325-336. CrossRef Medline

Lyons DB, Magklara A, Goh T, Sampath SC, Schaefer A, Schotta G, Lomvardas S (2014) Heterochromatin-mediated gene silencing facilitates the diversification of olfactory neurons. Cell Rep 9:884892. CrossRef Medline

Magklara A, Yen A, Colquitt BM, Clowney EJ, Allen W, MarkenscoffPapadimitriou E, Evans ZA, Kheradpour P, Mountoufaris G, Carey C, Barnea G, Kellis M, Lomvardas S (2011) An epigenetic signature for monoallelic olfactory receptor expression. Cell 145:555-570. CrossRef Medline

Markenscoff-Papadimitriou E, Allen WE, Colquitt BM, Goh T, Murphy KK, Monahan K, Mosley CP, Ahituv N, Lomvardas S (2014) Enhancer interaction networks as a means for singular olfactory receptor expression. Cell 159:543-557. CrossRef Medline

Mauser A, Holley-Guthrie E, Simpson D, Kaufmann W, Kenney S (2002) The Epstein-Barr virus immediate-early protein BZLF1 induces both a G(2) and a mitotic block. J Virol 76:10030-10037. CrossRef

Mclntyre JC, Bose SC, Stromberg AJ, McClintock TS (2008) Emx2 stimulates odorant receptor gene expression. Chem Senses 33: 825-837. CrossRef Medline

Mclntyre JC, Titlow WB, McClintock TS (2010) Axon growth and guidance genes identify nascent, immature, and mature olfactory sensory neurons. J Neurosci Res 88:3243-3256. CrossRef Medline

Michaloski JS, Galante PA, Malnic B (2006) Identification of potential regulatory motifs in odorant receptor genes by analysis of promoter sequences. Genome Res 16:1091-1098. CrossRef Medline

Miller AM, Treloar HB, Greer CA (2010) Composition of the migratory mass during development of the olfactory nerve. J Comp Neurol 518:4825-4841. CrossRef Medline

Monti Graziadei GA (1983) Experimental studies on the olfactory marker protein. III. The olfactory marker protein in the olfactory neuroepithelium lacking connections with the forebrain. Brain Res 262:303-308. Medline

Nickell MD, Breheny P, Stromberg AJ, McClintock TS (2012) Genomics of mature and immature olfactory sensory neurons. J Comp Neurol 520:2608-2609. CrossRef Medline

Novak A, Guo C, Yang W, Nagy A, Lobe CG (2000) Z/EG, a double reporter mouse line that expresses enhanced green fluorescent protein upon Cre-mediated excision. Genesis 28:147-155. Medline

O'Leary DD, Chou SJ, Sahara S (2007) Area patterning of the mammalian cortex. Neuron 56:252-269.

Pellegrini M, Mansouri A, Simeone A, Boncinelli E, Gruss P (1996) Dentate gyrus formation requires Emx2. Development 122:38933898. Medline

Plessy C, Pascarella G, Bertin N, Akalin A, Carrieri C, Vassalli A, Lazarevic D, Severin J, Vlachouli C, Simone R, Faulkner GJ, Kawai J, Daub CO, Zucchelli S, Hayashizaki Y, Mombaerts P, Lenhard B, Gustincich S, Carninci P (2012) Promoter architecture of mouse olfactory receptor genes. Genome Res 22:486-497.

Rabinowitz SS, Gordon S (1991) Macrosialin, a macrophagerestricted membrane sialoprotein differentially glycosylated in response to inflammatory stimuli. J Exp Med 174:827-836. Medline

Rodriguez I (2013) Singular expression of olfactory receptor genes. Cell 155:274-277. CrossRef Medline
Rodriguez-Gil DJ, Treloar HB, Miller A, Two A, Iwema C, Greer CA (2009) Onset of odorant receptors. Ann N Y Acad Sci 1170:18-20. CrossRef Medline

Rothman A, Feinstein P, Hirota J, Mombaerts P (2005) The promoter of the mouse odorant receptor gene M71. Mol Cell Neurosci 28:535-546. CrossRef Medline

Roy A, Gonzalez-Gomez M, Pierani A, Meyer G, Tole S (2014) Lhx2 regulates the development of the forebrain hem system. Cereb Cortex 24:1361-1372. CrossRef Medline

Salvatierra J, Lee DA, Zibetti C, Duran-Moreno M, Yoo S, Newman EA, Wang $\mathrm{H}$, Bedont JL, de Melo J, Miranda-Angulo AL, GilPerotin S, Garcia-Verdugo JM, Blackshaw S (2014) The LIM homeodomain factor Lhx2 is required for hypothalamic tanycyte specification and differentiation. J Neurosci 34:16809-16820. CrossRef Medline

Sammeta N, Yu TT, Bose SC, McClintock TS (2007) Mouse olfactory sensory neurons express 10,000 genes. J Comp Neurol 502: 1138-1156. CrossRef Medline

Schwob JE, Szumowski KE, Stasky AA (1992) Olfactory sensory neurons are trophically dependent on the olfactory bulb for their prolonged survival. J Neurosci 12:3896-3919. Medline

Serizawa S, Miyamichi K, Nakatani H, Suzuki M, Saito M, Yoshihara Y, Sakano H (2003) Negative feedback regulation ensures the one receptor-one olfactory neuron rule in mouse. Science 302:20882094. CrossRef Medline

Shetty AS, Godbole G, Maheshwari U, Padmanabhan H, Chaudhary R, Muralidharan B, Hou PS, Monuki ES, Kuo HC, Rema V, Tole S (2013) Lhx2 regulates a cortex-specific mechanism for barrel formation. Proc Natl Acad Sci U S A 110:E4913-E4921. CrossRef Medline

Shykind BM, Rohani SC, O'Donnell S, Nemes A, Mendelsohn M, Sun Y, Axel R, Barnea G (2004) Gene switching and the stability of odorant receptor gene choice. Cell 117:801-815. CrossRef Medline

Song HJ, Stevens CF, Gage FH (2002) Neural stem cells from adult hippocampus develop essential properties of functional CNS neurons. Nat Neurosci 5:438-445. CrossRef Medline

Song L, Lee C, Schindler C (2011) Deletion of the murine scavenger receptor CD68. J Lipid Res 52:1542-1550. CrossRef Medline

Storey JD, Tibshirani R (2003a) Statistical significance for genomewide studies. Proc Natl Acad Sci U S A 100:9440-9445.

Storey JD, Tibshirani R (2003b) Statistical methods for identifying differentially expressed genes in DNA microarrays. Methods Mol Biol 224:149-157. CrossRef Medline

Suzuki Y, Schafer J, Farbman Al (1995) Phagocytic cells in the rat olfactory epithelium after bulbectomy. Exp Neurol 136:225-233. CrossRef Medline

Takeuchi H, Inokuchi K, Aoki M, Suto F, Tsuboi A, Matsuda I, Suzuki M, Aiba A, Serizawa S, Yoshihara Y, Fujisawa H, Sakano H (2010) Sequential arrival and graded secretion of Sema3F by olfactory neuron axons specify map topography at the bulb. Cell 141:10561067. CrossRef Medline

Vassalli A, Feinstein P, Mombaerts P (2011) Homeodomain binding motifs modulate the probability of odorant receptor gene choice in transgenic mice. Mol Cell Neurosci 46:381-396. CrossRef Medline

Wang SS, Lewcock JW, Feinstein P, Mombaerts P, Reed RR (2004) Genetic disruptions of O/E2 and O/E3 genes reveal involvement in olfactory receptor neuron projection. Development 131:13771388. CrossRef

Watt WC, Sakano H, Lee ZY, Reusch JE, Trinh K, Storm DR (2004) Odorant stimulation enhances survival of olfactory sensory neurons via MAPK and CREB. Neuron 41:955-967. Medline

Zhao S, Tian H, Ma L, Yuan Y, Yu CR, Ma M (2013) Activity-dependent modulation of odorant receptor gene expression in the mouse olfactory epithelium. PLoS One 8:e69862. CrossRef Medline 